This report was funded by the Bonneville Power Administration (BPA), U.S. Department of Energy, as part of BPA's program to protect, mitigate, and enhance fish and wildlife affected by the development and operation of hydroelectric facilities on the Columbia River and its tributaries. The views in this report are the author's and do not necessarily represent the views of BPA.

For additional copies of this report, write to:

\author{
Bonneville Power Administration \\ Public Information Center - CKPS-1 \\ P.O. Box 3621 \\ Portland, OR 97208
}




\title{
MOVEMENT AND INJURY RATES FOR THREE LIFE STAGES OF SPRING CHINOOK SALMON ONCORHYNCHUS TSHAWYTSCHA: A COMPARISON OF SUBMERGED ORIFICES AND AN OVERFLOW WEIR FOR FISH BYPASS IN A MODULAR ROTARY DRUM FISH SCREEN
}

\section{ANNUAL REPORT 1995}

\author{
Prepared by: \\ C. Scott Abernethy \\ Duane A. Neitzel \\ William V. Mavros \\ Pacific Northwest National Laboratory \\ Richland, WA
}

Prepared for:

U. S. Department of Energy

Bonneville Power Administration

Environment, Fish and Wildlife

P.O. Box 3621

Portland, OR 97208-3621

Project Number 86- 118

Task Order DE-AT79-94BP30373/BPA

Contract Number DE-AI79-86BP626 11

March 1996 


\section{Preface}

The Bonneville Power Administration is funding the construction and installation of fish passage and protection facilities at irrigation diversions in the Lemhi River Basin, Idaho. The construction implements Sections 1400 4.2, Project 84-028, of the Northwest Power Planning Council's 1984 and 1987 Columbia River Fish and Wildlife Program. ${ }^{\text {(a) }}$ This program provides for enhancement measures to compensate for fish and wildlife losses caused by hydroelectric development throughout the Columbia River Basin. The addition and improvement of facilities in the Lemhi Basin are meant to increase the survival of salmon to help mitigate the impacts of irrigation in the Lemhi River Basin.

A modular 4-ft long, 2-ft diameter rotary drum screen unit and similar screens are planned for use at diversion sites throughout the Lemhi Basin. This study evaluates fish survival and movement through submerged orifices used to control flow in the fish bypass. Tests were conducted with 2-in. and 6-in. orifices and an overflow weir. Fish movement depended on fish size and the orifice used. Few injuries were detected during these tests.

(a) NPPC (Northwest Power Planning Council). 1987. Columbia River Basin Fish and Wildlife Program, Portland, Oregon. 


\section{Acknowledgments}

The success of this project depended on the involvement and cooperation of many people. This project was managed by Jodi Strocklund, Bonneville Power Administration (BPA). Tom Clune and Deborah New managed this project when the idea of testing modular fish screens in a laboratory was first proposed. Ms. New was instrumental in bringing the first modular screen to PNNL for these tests. Chuck Keller, Bureau of Reclamation, on assignment with the Idaho Department of Fish and Game (IDFG), acted as liaison and helped coordinate the acquisition and setup of the test system. John Easterbrooks and Pat Schille, Washington Department of Fish and Wildlife (WDFW), provided the modular fish screen used in the tests and gave input on screen operation and maintenance. Lynn Stratton and Jim Jones, IDFG, and their screen fabrication and maintenance staff provided enthusiastic support and assistance. Brad Gilmore helped set up the test system. Annette Hoffmann provided input on experimental design. Gregg Martenson, Susan Blanton, and student Mark Tennier helped monitor the tests and provided other technical assistance during the project. The manuscript was reviewed by Dale Becker and Gary Johnson, and edited by Melanie DeSmet. 


\section{Abstract}

The Pacific Northwest National Laboratory (PNNL) ${ }^{\text {(a) }}$ evaluated the effectiveness of 6-in. and 2-in. submerged orifices, and an overflow weir for fish bypass at a rotary drum fish screening facility. A modular drum screen built by the Washington Department of Fish and Wildlife (WDFW) was installed at PNNL's Aquatic Ecology research laboratory in Richland, Washington. Fry, subyearlings, and smolts of spring chinook salmon (Oncorhynchus tshawytscha) were introduced into the test system, and their movement and injury rates were monitored. A total of 33 tests (100 fish per test) that lasted from 24 to $48 \mathrm{hr}$ were completed from 1994 through 1995.

Passage rate depended on both fish size and bypass configuration. For fry/fingerling spring chinook salmon, there was no difference in passage rate through the three bypass configurations (2-in. orifice, 6-in. orifice, or overflow weir). Subyearlings moved sooner when the 6-in. orifice was used, with more than 50\% exiting through the fish bypass in the first $8 \mathrm{hr}$. Smolts exited quickly and preferred the 6-in. orifice, with over $90 \%$ of the smolts exiting through the bypass in less than $2 \mathrm{hr}$. Passage was slightly slower when a weir was used, with $90 \%$ of the smolts exiting in about $4 \mathrm{hr}$. When the 2-in. orifice was used in the bypass, $90 \%$ of the smolts did not exit until after $8 \mathrm{hr}$. In addition, about $7 \%$ of the smolts failed to migrate from the forebay within $24 \mathrm{hr}$, indicating that smolts were significantly delayed when the 2 -in. orifice was used.

Few significant injuries were detected for any of the life stages. However, light descaling occurred on about $15 \%$ of chinook salmon smolts passing through the 2 -in. orifice. Although a single passage through the orifice did not appear to cause significant scale loss or other damage, passing through several screening facilities with 2 -in. orifices could cause cumulative injuries.

No impingement or entrainment was observed when the screening facility was operated within its designed flow and submergence limits. Approach and sweep velocity vectors in front of the screen were slightly affected by bypass configuration and flow. Velocity vectors did not appear to play a significant role in attracting fish to the bypass. Fish easily found the fish bypass despite varied flow conditions and exited through the fish bypass volitionally.

(a) The Pacific Northwest National Laboratory is operated by Battelle for the U.S. Deparment of Energy under Contract DE-AC06-76RLO 1830. 
viii 


\section{Contents}

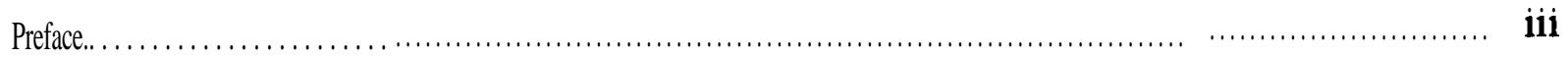

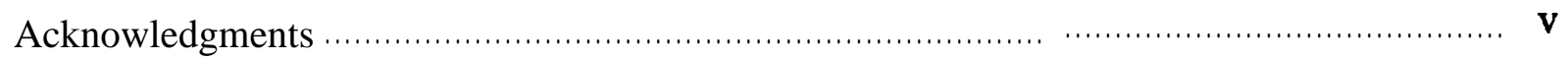

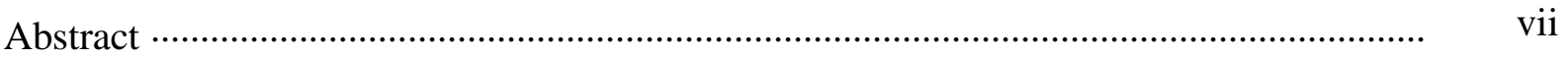

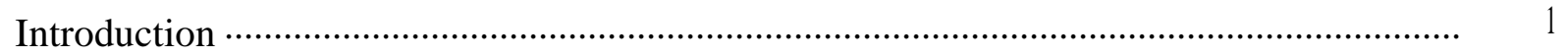

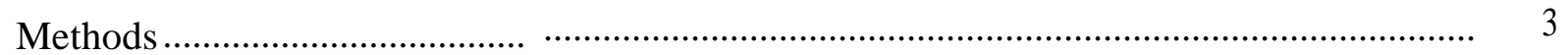

Modular Fish Screen Test System …............................................................ 3

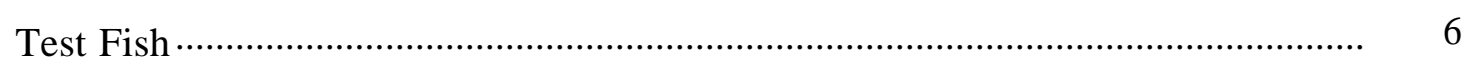

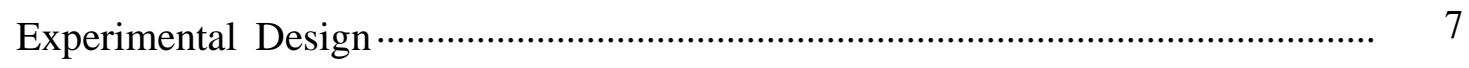

Statistical Analysis …............................................................................... 8

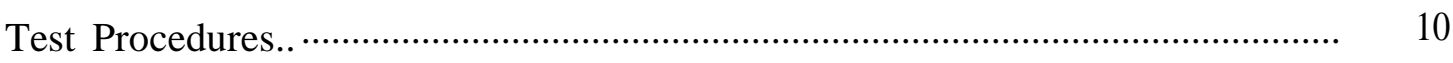

Flow and Velocity Measurement.. ….............................................................. 11

Monitoring Fish Behavior with Underwater Video …....................................... 11

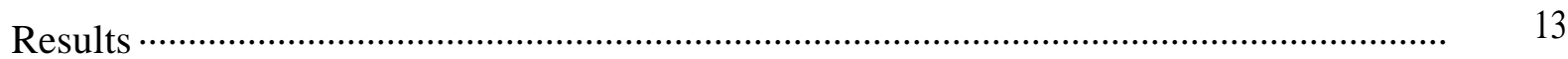

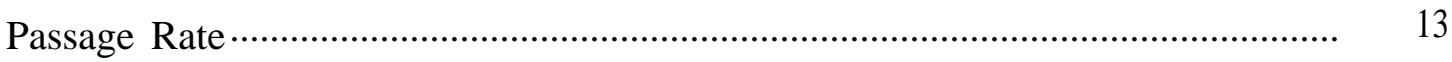

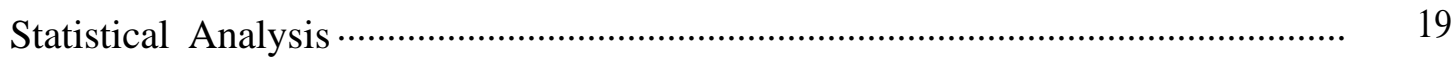

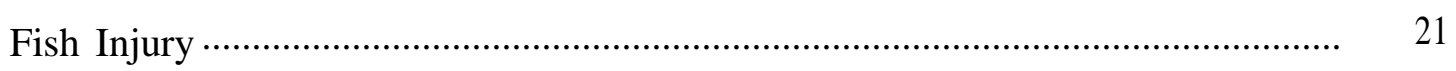

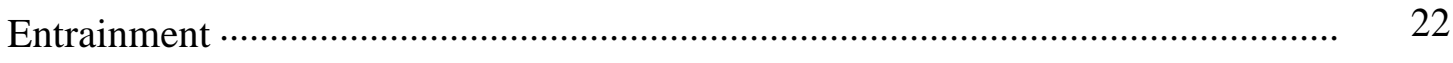

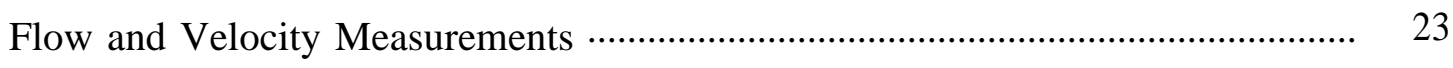

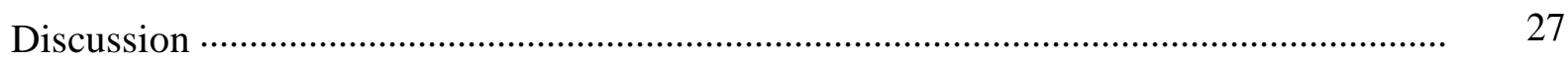

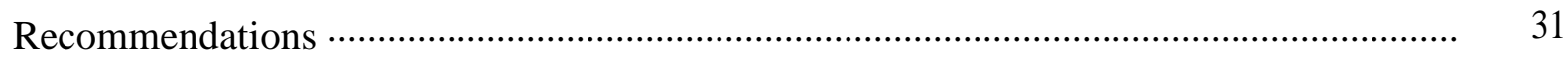

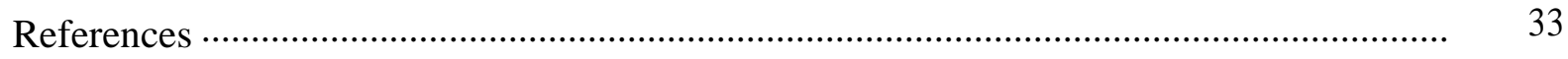




\section{Figures}

1 View of Modular Fish Screen Test System Installed at the Pacific Northwest National Laboratory in Richland, Washington ........................................... 3

2 Test System to Conduct In Vivo Fish Passage Tests with a Modular Fish

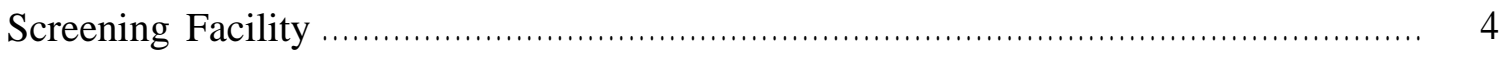

3 Head-On View of Adjustable Orifice Gate Mounted in the Weir Slot of the Modular Fish Screen Test System ............................................................ 6

4 Movement of Fry Spring Chinook Salmon by Sampling Interval During In Vivo

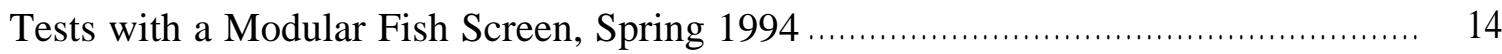

5 Cumulative Recovery of Fry Spring Chinook Salmon During In Vivo Tests with a

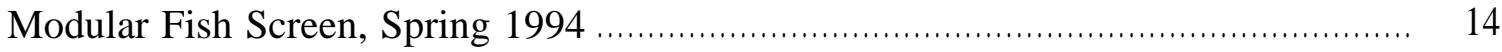

6 Movement of Subyearling Spring Chinook Salmon by Sampling Interval During In Vivo Tests with a Modular Fish Screen, Spring 1994 .................................... 17

7 Cumulative Recovery of Subyearling Spring Chinook Salmon During In Vivo

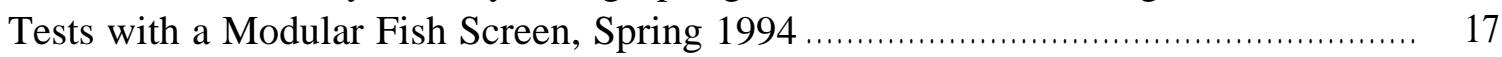

8 Movement of Smolt Spring Chinook Salmon by Sampling Interval During In Vivo

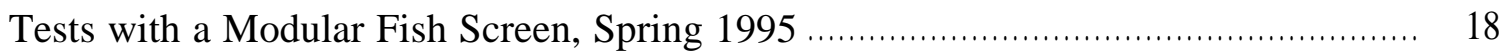

9 Cumulative Recovery of Smolt Spring Chinook Salmon During In Vivo Tests with a Modular Fish Screen, Spring 1995 ............................................................. 19

10 Velocity Profile in Front of the Drum Screen and in the Fish Bypass Slot with a 2-in. Orifice used for Fish Bypass ........................................................... 24

11 Velocity Profile in Front of the Drum Screen and in the Fish Bypass Slot with a 6-in. Orifice used for Fish Bypass ................................................................... 24

12 Velocity Profile in Front of the Drum Screen and in the Fish Bypass Slot with a Weir used for Fish Bypass 
xii 


\section{Tables}

1 Number of Fry/Fingerling Spring Chinook Salmon that Moved Through the Bypass During Sample Intervals in Orifice Tests with a Modular Fish Screen,

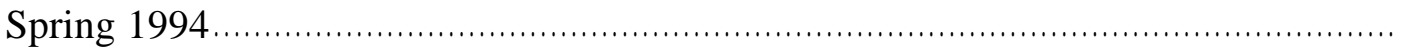

2 Number of Subyearling Spring Chinook Salmon that Moved Through the Bypass During Sample Intervals in Orifice Tests with a Modular Fish Screen, Spring 1994.

3 Number of Smolt Spring Chinook Salmon that Moved Through the Bypass During Sample Intervals in Orifice Tests with a Modular Fish Screen, Spring 1995

$4 \quad$ Single Factor ANOVA for Spring Chinook Fry, Subyearlings, and Smolts Comparing the Three Different Bypass Configurations: 2-in. Orifice, 6-in. Orifice, and Overflow Weir at 1 and $8 \mathrm{hr}$.

5 Tukey's Multiple Comparison at $\mathrm{P} \leq 0.05(\mathrm{CI}=$ Confidence Interval $) \ldots \ldots \ldots \ldots \ldots \ldots \ldots \ldots$

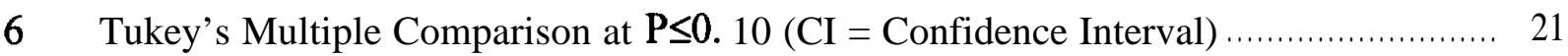

7 Estimate of Partial Descaling Rate for Smolt Spring Chinook Salmon After Passing Through the Fish Bypass in a Modular Fish Screen

8 Comparison of Bypass Flow Through Different Bypass Configurations Using Three Measurement Methods..... 


\section{Introduction}

Water from the Columbia River drainage has been used for irrigation since the first homesteaders arrived in the Pacific Northwest in the mid-1 850s. Screening of irrigation diversions to protect fish dates back more than 50 years. Passage of the Mitchell Act in 1938 to mitigate the impact of federal dams on anadromous fish provided the funds that initiated the current screening programs in Washington, Oregon, and Idaho. The Northwest Power Planning Council (NPPC), through its 1984 and 1987 Columbia River Fish and Wildlife Program, has listed fish protection through effective screening of diversions as an essential element in their program to restore dwindling salmon and steelhead runs.

Since the first diversion screens were built, criteria used to measure their effectiveness have become much more stringent (Bates 1988). The allowable approach velocity at the face of screens has been reduced and sweep velocities to provide guidance to the fish bypass system have been raised. In addition, smaller mesh sizes for screens are now required to prevent small fish from passing through the screens and becoming entrained in irrigation canals. The new requirements, developed and approved by the National Marine Fisheries Service (NMFS) and fisheries agencies from Idaho, Oregon, and Washington, have resulted in the need to develop new screen designs to replace older, less effective facilities. In order to measure the effectiveness of new screens, the Bonneville Power Administration (BPA) established a monitoring and evaluation program to ensure that screening facilities meet fish protection goals.

From 1985 through 1990, fisheries evaluations were completed at many large screening facilities in the Yakima River Basin (Neitzel et al. 1985, 1986, 1988, 1990a,b,c). These evaluations relied heavily on release-and-recapture tests with hatchery fish to monitor passage rate, injury rate, and entrainment of fish at each site. Native fish were also monitored in the studies. Although some site-specific problems were encountered, most problems with design, operation, or maintenance were common to several sites. Therefore, solutions to problems encountered at one screening site were usually applicable to similar problems at other sites.

As part of the NPPC's Columbia River Fish and Wildlife Program, irrigation diversions in Idaho are being improved. BPA asked the Pacific Northwest National Laboratory (PNNL) to evaluate the design, construction, and operation of fish screens in Idaho. The Salmon River Basin has several hundred irrigation diversions. Most of the diversions are small and supply only one irrigator with water. Although most diversions are screened, many of the facilities were built decades ago and no longer comply with fish protection standards. The Lemhi River is a tributary that enters the Salmon River near Salmon, Idaho. There are over 80 irrigation diversions in the lower 50 miles of the Lemhi River, and many of the screening facilities are now being replaced with modern screens.

Due to the large number of screening facilities involved in the program, it is not possible or economically feasible to conduct capture-and-release fisheries tests to evaluate each site. In addition, the Lemhi River has been classified as a "native stock" river, which excludes the 
planting of hatchery-reared fish for research purposes. Due to the very limited numbers of native salmonid populations remaining in the Lemhi River today, it would be very difficult to capture enough native fish to make a valid evaluation of a facility. Protection for spring chinook salmon (Oncorhynchus tshawytscha) under the Endangered Species Act also severely restricts or eliminates many sampling and collection methods required to complete an onsite evaluation.

With funding from BPA, the Washington Department of Fish and Wildlife (WDFW) has designed a modular fish screen for use in small irrigation diversions. Similar modular fish screens are being designed and built by the Oregon Department of Fish and Wildlife (ODFW) and the Idaho Department of Fish and Game (IDFG). Although the modular screens for small diversions are $10-\mathrm{ft}$ wide or less, their construction and operation is very similar to those at larger screening facilities and similarly-sized screens mounted on permanent concrete structures.

The development of the modular fish screening facility has made it possible to conduct fisheries evaluations under controlled laboratory conditions to address questions related to their design, operation, and maintenance. The test system can be used to monitor injury rates, impingement, entrainment, passage rate, and velocity vectors in front of the screen and in the fish bypass system. Operating conditions such as screen submergence, flow through the screen, and bypass flow can be precisely controlled and easily changed. The number, size, and species of fish used in tests can be chosen without restrictions mandated by the Endangered Species Act. Tests can also be standardized and replicated to produce a high degree of precision to the evaluation process. The use of a modular fish screen for laboratory testing reduces the cost of test completion and evaluation, saves time, and provides answers to critical questions before screens are installed and put into service. A modular fish screen was installed at the PNNL in 1993.

Submerged orifices are used to control flow at most fish screening facilities in Idaho. Therefore, a submerged orifice was used for tests with the modular fish screen to evaluate passage. We chose spring chinook salmon as our test species because stocks returning to the Salmon River Basin are listed as endangered and they are the salmonid most likely to encounter the fish diversion conditions we evaluated in our research. Tests were conducted during 1994 and 1995 with three life stages of spring chinook salmon: fry/fingerlings, subyearlings, and smolts. This report describes how a modular fish screen was used as a test system, methods used to evaluate its performance, and test results. The findings and implications of the results are discussed and recommendations for orifice use and design are provided. 


\section{Methods}

\section{Modular Fish Screen Test System}

The modular fish screen used in our evaluation tests was designed and built by WDFW Fish Screen Fabrication Shop in Yakima, Washington. The rotary drum fish screen is 4-ft long and 2 -ft in diameter. The drum screen is constructed of stainless steel perforated plate with $1 / 8$-in. holes, providing about $28 \%$ opening in the material. The screen is mounted within a steel structure that consists of modular sections (forebay section, bypass, screen section, transition section, and paddle wheel section) bolted together (Figures 1,2).

The modular screen was positioned on a gravel pad (above ground) next to a concrete raceway used as a recirculation tank ( $40-\mathrm{ft}$ long by 4.5 - $\mathrm{ft}$ wide by 3 - $\mathrm{ft}$ deep, -4000 gal volume). The gravel pad was used to bring the bottom. of the fish screen up to level with the top of the raceway wall, insuring that water could flow freely through the screen flume and fish bypass. The paddle wheel section was reinforced with I-beams to prevent the sides from spreading when the system was filled with water. No other structural modifications were required to operate the screen above ground level. A discharge flume (1-ft wide, 2-ft tall, and about 8-ft long, with a 90 " curve at the head end) was fastened to the end of the paddle wheel section to return water to the recirculation tank.

A 7.5 horsepower centrifugal pump with a pumping capacity of 3.3 cubic feet per second (cfs), or -1500 gallons per minute (gpm) was installed over the raceway/recirculation tank. Flow through the pump was controlled by a gate valve in the discharge line from the pump. Water was delivered to a head box ( 4-ft wide by 5-ft long) attached to the forebay of the modular fish screen. The recirculation tank was supplied with both ambient Columbia River water and well water at $-17^{\circ} \mathrm{C}$. Water sources were mixed to maintain the desired test temperature. Water in the test system was replaced every $3 \mathrm{hr}$ by continuously adding 25 gallons per minute $(\mathrm{gpm})$ of water.

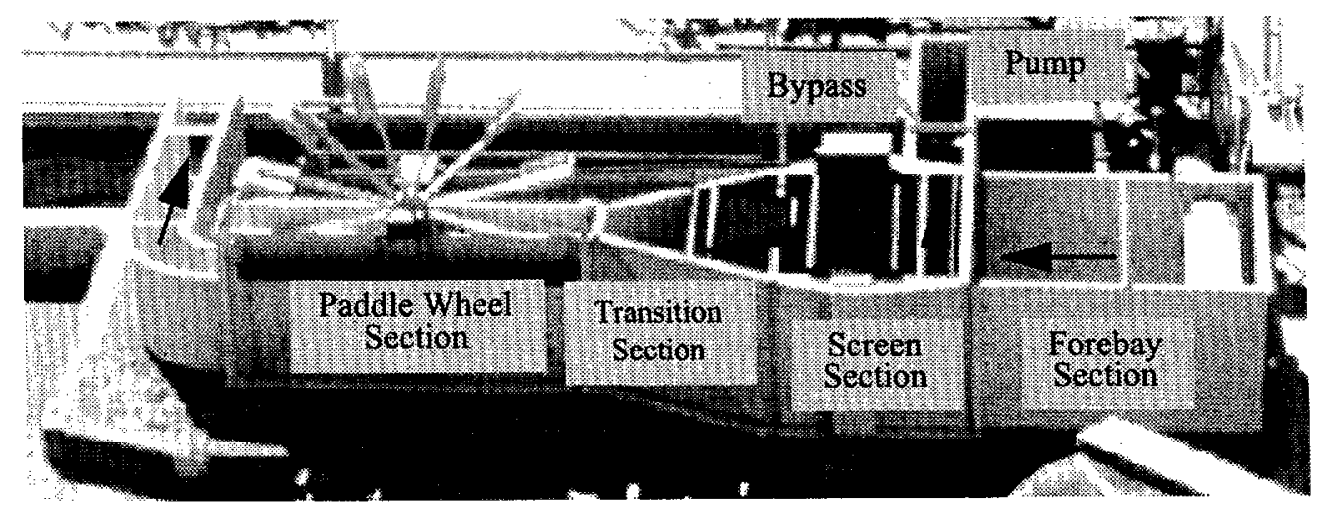

Figure 1. View of Modular Fish Screen Test System Installed at the Pacific Northwest National Laboratory in Richland, Washington 


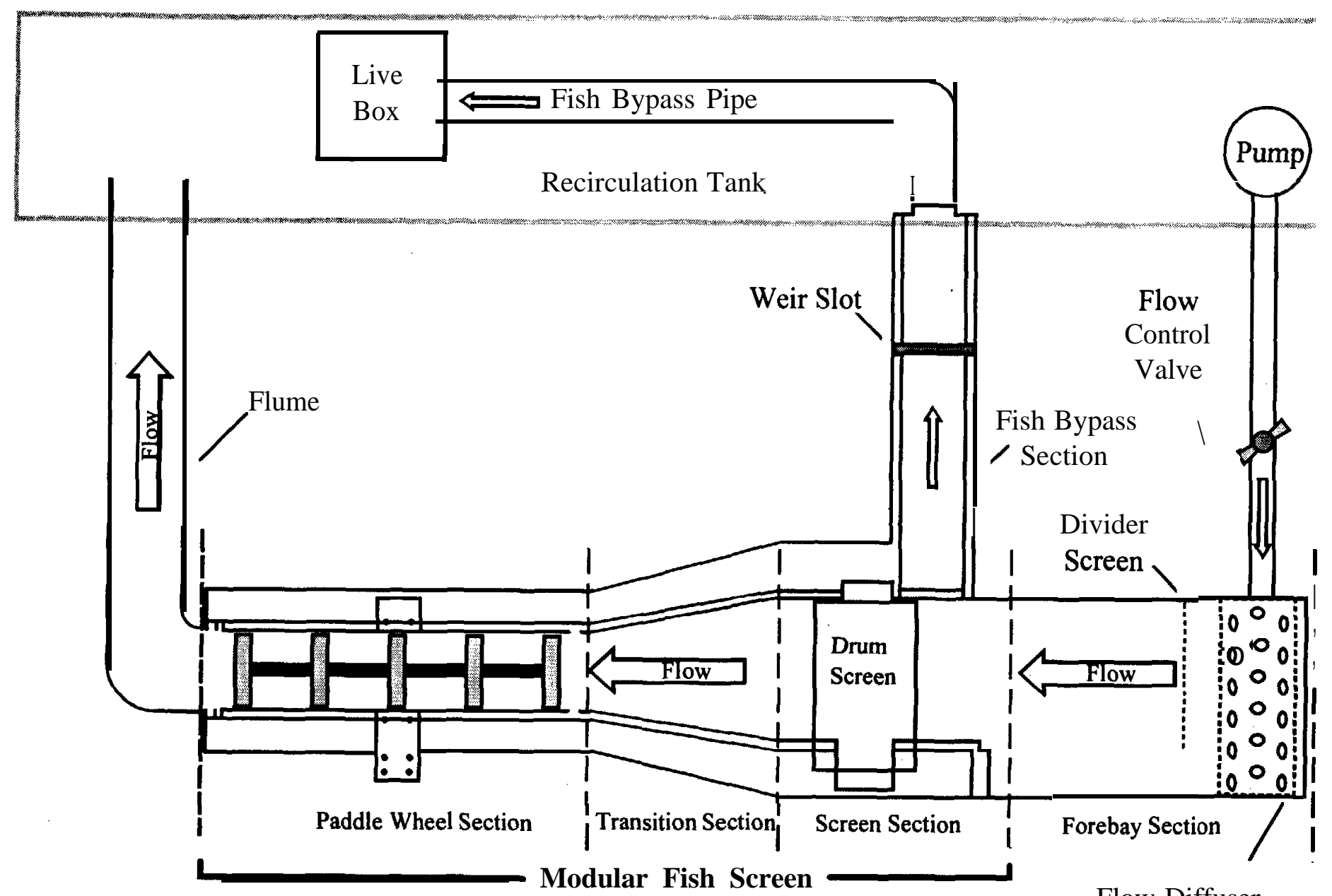

Flow Diffuser

Figure 2. Test System to Conduct In Vivo Fish Passage Tests with a Modular Fish Screening Facility 
A diffiser (section of pipe with large holes drilled in it along its length) and concrete blocks were used to reduce water turbulence within the head box. In addition, an aluminum perforated plate with 3/32-in. holes was installed between the diffuser and the screen forebay section to further reduce turbulence and to prevent fish from moving upstream into the head box area during tests. When assembled, the "footprint" of the entire fish screen test system was about 22-ft long and 10-ft wide (including the bypass flume and discharge flume). Water level was maintained at the screen by placing an overflow weir in the entrance to or behind the paddle wheel section. The height of the weir was adjusted so that about $1.75 \mathrm{cfs}$ of water passed through the screen at $85 \%$ submergence.

In the state of Washington, bypass flow is usually maintained and controlled by an overflow weir in the fish bypass. Our test system used the "standard' fish bypass provided by WDFW. The fish bypass section was 6.5-e long, 1-ft wide, and had a slot for insertion of weir boards about $4.5 \mathrm{ft}$ from the entrance to the fish bypass. The fish bypass section ended with a sleeve that was coupled to an 8-in. PVC pipe. Due to spatial restrictions, we added an 90" elbow to the fish bypass line so the return pipe could be extended to an overall length of about $30 \mathrm{ft}$ and still discharge into the recirculation tank. An inclined plane (surface of stainless steel perforated plate with 1/8-in. holes) with a live box was placed at the terminus of the fish return pipe to capture and hold fish as they exited.

The fish bypass configuration of the modular fish screen differed from typical screening facilities used in Idaho, where a submerged orifice bypass is preferred over the weir bypass. Low head differential and fluctuating water levels at most sites make it difficult to maintain a reliable flow over a weir. At older sites, the entrance to the submerged orifice is usually flush with the side wall of the screen forebay. At some sites, the bypass pipe extends out into the screens forebay. At newer sites, a recessed head box about $2 \mathrm{ft}^{2}$ is provided to give fish a "transition" area where fish can "adapt" before entering the fish return pipe. Bypass pipe diameter ranges from $4 \mathrm{in}$. at old sites to $10 \mathrm{in}$. at new sites.

The bypass gate used in our tests was provided by the IDFG. The gate is fabricated from 1/8-in. steel plate and is "adjustable" to provide flow through either a 2-in. or 6-in.

horseshoe-shaped orifice (Figure 3). A false wall was fabricated from plywood and positioned in the weir board slot of the fish bypass. The adjustable gate was installed in guides fastened to the front of the wall. A PVC flange mounted on the back side of the wall and a short section of 8-in. pipe were used to couple the wall to the fish return pipe.

Our test series was designed to evaluate how bypass configuration ( 2 orifice sizes or weir) and the resultant bypass flow affected movement and injury rates for fish. The overflow weir was used as a "control" to evaluate overall submerged orifice performance. Bypass configuration could be changed from the submerged orifice to an overflow weir by removing the adjustable gate, false wall, and short pipe section, and adding weir boards. The weir height was $4.5 \mathrm{in}$. lower than the forebay depth to provide about $0.75 \mathrm{cfs}$ of flow when the drum screen was at $85 \%$ submergence. Conversion took less than 5 minutes. 


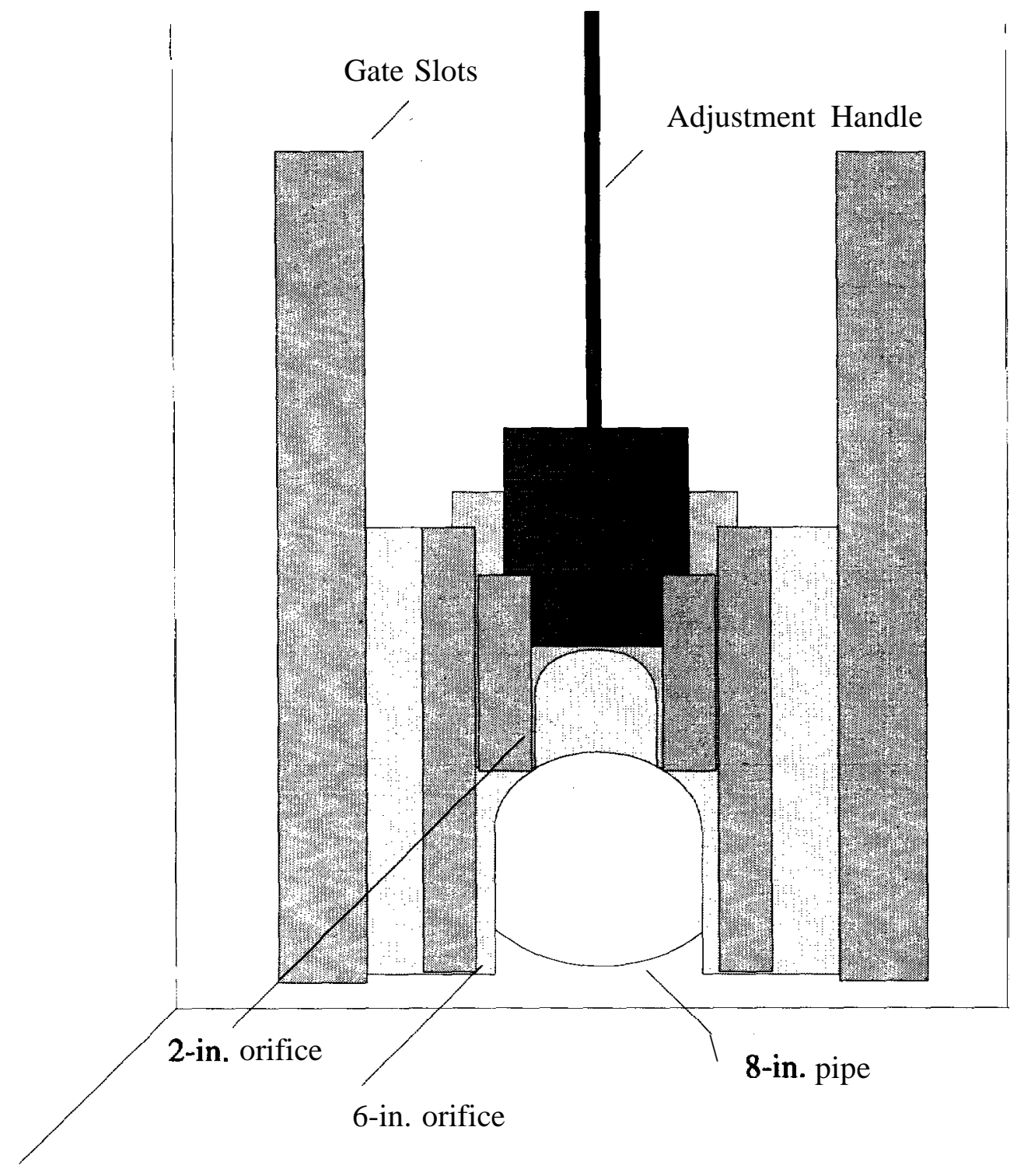

Figure 3. Head-On View of Adjustable Orifice Gate Mounted in the Weir Slot of the Modular Fish Screen Test System

\section{Test Fish}

Spring chinook salmon utilize the Salmon River Basin and are a primary species of concern in Idaho, where submerged orifices are commonly employed to control flow through the fish bypass at fish screening facilities. We used spring chinook salmon stocks from the Leavenworth National Fish Hatchery in Leavenworth, Washington, for out tests. In mid-August 1993, eggs and milt were collected from six pairs of salmon and the gametes were transported to PNNL's research hatchery. The eggs were fertilized and incubated in a vertical flow incubator. In mid-November, about 4500 alevins were transferred to two fry troughs (10-ft long, 1-ft wide, 
0.6-e deep, 40-gal capacity). Fry were maintained in troughs throughout the first test series (fry, 45-60 mm fork length [FL]). Approximately 1500 fish were used in the fry test series. In March 1994, the remaining fingerlings (- 3000 fish) were transferred to a fiberglass circular tank (6-ft diameter, 3-ft deep, 600-gal capacity) and held until they were large enough to use in the second test series (subyearlings, 90-1 $00 \mathrm{~mm}$ FL). About 1200 fish were used in the subyearling test series. The remaining fish (- 1800 fish) were maintained through the winter in two circular tanks (6-ft diameter, 3-ft deep, 600-gal capacity) and were used in the smolt test series in April 1995. Test fish were only used once to prevent individual fish from "learning" how to migrate through the test system.

\section{Experimental Design}

The purpose of these tests was to compare the performance of two submerged orifices in providing safe fish passage for juvenile salmonids. The null hypothesis (Ho:) being tested was that there is no difference in passage or injury rate, based on three different bypass configuration that juvenile salmonids might encounter when exiting a fish screening facility. The variables for this experiment are:

- 3 bypass configurations

- 2-in. submerged orifice (treatment)

- 6-in. submerged orifice (treatment)

- overflow weir (control)

- fish size (life stage)

- emergent spring chinook salmon fry (45-60 mm)

- $\quad$ subyearling spring chinook salmon (80-1 $10 \mathrm{~mm})$

- $\quad$ spring chinook salmon smolts (120-1 $80 \mathrm{~mm}$ ).

We used a Randomized Complete Block Design (RCBD) with the bypass configuration type as treatments and passage time as the blocks. Each block contains each treatment and is divided by life stage. The test design removes random variability in one direction as well as reducing variation within blocks. In order to further reduce variance, there was no temporal order of preference for selection of treatments (random number generator was used to determine test order) and control and there were at least 3 replicates per treatment. Replications of treatments were used to reduce random error, inherent variability among experimental units, and chance events (Snedecor and Cochran 1967). There were 3 possible treatments (combinations) with 4 replicates each for a minimum of 12 runs per fish life stage (except for smolts, where only 3 replicates [9 tests] were conducted due to a fish shortage). 
One hundred test fish were introduced in the forebay (in front of the screens) in each test. Fish encountered one of three bypass configurations. The number of fish passing through the bypass were counted at $1,2,4,8,24$, and $48 \mathrm{hr}$. Tests continued at least $24 \mathrm{hr}$ and up to $48 \mathrm{hr}$. At termination we counted:

1) the number of fish remaining in front of the screen (residual), exiting the bypass, or missing

2) number of fish injured or killed

3) average passage time for fish exiting through the bypass.

\section{Statistical Analysis}

Prior to initiating the test series, we conducted a preliminary power analysis to determine the sample size necessary to detect a significant $(\mathrm{P}<0.05)$ difference in passage rate among bypass configurations. Statistical power is the probability of correctly rejecting the null hypothesis, that we could detect differences that really exist (Cohen 1977). A high power was desired so that the occurrence of a Type II error was minimized. A Type II error results when it is concluded that no impact has occurred even though one has (Green 1989). The highest power for the fewest number of fish per test is always the desired goal, but there are always constraining circumstances that confound this. We were looking for the best possible combination of number of fish per test and number of replicates that would fit our budget and fish resources.

We want to maximize $\mathrm{f}$, so at $\mathrm{n}=100$ fish

$$
\begin{aligned}
& \phi=1 / \sigma \sqrt{\frac{r \sum(\rho-\bar{\rho})^{2}}{t}} \\
& \phi=\text { power of test } \\
& n=\# \text { of fish per test } \\
& r=\# \text { of replicates per treatment } \\
& t=\# \text { of treatments } \\
& \rho=\text { number of fish passed per test run } \\
& \bar{\rho}=\text { average number of fish passed }
\end{aligned}
$$

$$
\sigma=\sqrt{\frac{(1-\rho) p}{n}}
$$

$\boldsymbol{\sigma}=$ variability or uncertainty in each test run. 
We calculated an apriori power of $31 \%$ for passage of 100 fish after $1 \mathrm{hr}$, when we assumed a bypass rate of $20 \%$ for the 2 -in. orifice, $40 \%$ for the 6 -in. orifice, and $30 \%$ for the weir. Power was increased to $38 \%$ when 200 fish were used and to $56 \%$ when 500 fish were used. If we doubled the replicates from four to eight, we increased the power to $43 \%$.

Post-hoc power analysis example of the $8 \mathrm{hr}$ passage interval for sub-yearlings is:

$$
\begin{aligned}
& n=100 \\
& \rho=4 \\
& t=4 \\
& \bar{r}=0.47 \\
& s=0.0419 \\
& \phi=1 / s \sqrt{\frac{r \sum(\rho-\bar{\rho})^{2}}{t}} \\
& \phi=0.0149 \sqrt{0.0439} \\
& \phi=4.19 .
\end{aligned}
$$

We now have $\phi=4.19, F_{\text {crit }}=4.256\left(\mathrm{~F}_{\text {crit }}\right.$ is the critical $F$ statistic obtained from ANOVA), between group $\mathbf{d f}=\mathbf{2}$, within group $\mathbf{d f}=\mathbf{9}$. By using power tables we calculate power to be equal to $32 \%$.

A single factor analysis of variance (ANOVA) was used to detect if there were significant differences in bypass rates among the different bypass configurations (Snedecor and Cochran 1967). The counts of the related samples were matched in groups (orifice types) and comparisons were made among groups and within groups. This analysis was extended to compare further groupings of the same counts. Two different sampling intervals were selected ( $1 \mathrm{hr}$ and $8 \mathrm{hr}$ ). The $1 \mathrm{hr}$ interval was selected to capture the instantaneous movement of juvenile chinook salmon as they encounter the bypass screen and/or orifice. The $8 \mathrm{hr}$ interval was selected because our tests were initiated so that the $8 \mathrm{hr}$ monitoring interval occurred about 0.5 to $1 . \mathrm{O} \mathrm{hr}$ after sundown, a period of peak movement for juvenile salmonids.

The ANOVA will only indicate if there is a difference among bypass configurations. Therefore, we used the Tukey method of multiple comparisons to determine differences between specific pairs of bypass configurations (Neter et al. 1985). This test is a multiple comparison procedure where the family of statements includes all the possible statements one anticipates might be made after the data are examined. If the null hypothesis is rejected $(\mathrm{P} \leq 0.05)$, we can conclude that there is at least one inequality among the means of the treatment groups (or among the treatment effects). Tukey's test compares the difference between the confidence intervals (CIs) of the number of fish passed by each configuration. This test is used to decide which pairs 
of bypass configuration treatments are different. In all cases, the sample sizes are equal for the treatment groups.

The CI is calculated with the Tukey multiplier:

Tukey multiplier for $0.05=3.95 / 1.41$

Tukey multiplier for $0.10=3.32 / 1.41$

$$
C I=\hat{D} \pm(T) S D(\hat{D})
$$

$$
\begin{aligned}
& \hat{D}=\text { difference of means } \\
& T=\text { Tukey multiplier }
\end{aligned}
$$

$M S E=$ mean squared error (from ANOVA analysis)

$n=$ number of replicates

$$
S D=\text { standard deviation of difference }=\sqrt{\operatorname{MSE}\left(\frac{1}{n}+\frac{1}{n}\right)}
$$

\section{Test Procedures}

The recirculation tank and test system were drained and refilled with fresh water at the desired test temperature. When the appropriate bypass configuration was in place, the pump was turned on and the modular screen was filled. Water level in the screen forebay was set to provide $\sim 85 \%$ submergence by adjusting the control valve in the pump discharge line. Flow and water levels were allowed to stabilize for about $0.5 \mathrm{hr}$ before approach velocity, canal flow, bypass flow, and temperature measurements were taken. For the fry and subyearling tests, 100 fish were placed in floating net pen $(1.5 \mathrm{ft}$ by $1 \mathrm{ft}$ by $1.5 \mathrm{ft}$ deep, constructed of perforated aluminum with 3/32-in. holes) suspended in the upstream end of the screen forebay. For smolt tests, 100 fish were placed in a 21 gal perforated plastic garbage can. After allowing $1 \mathrm{hr}$ for the fish to acclimate, the containers were submerged and tipped to release the fish in front of the screen.

The live box at the end of the fish bypass pipe was checked at 1, 2, 4, 8, 24, and $48 \mathrm{hr}$ after test startup. Sampling intervals at $0.25,0.5$, and $0.75 \mathrm{hr}$ were added for the smolt test series. Tests were started from late morning to early afternoon so that the 8-hr check would occur about $1 \mathrm{hr}$ after sunset, the time when we expected most fish would exit the system. Recovered fish were counted and examined for injuries. We also measured fork lengths of bypassed and residual fish to determine if fish size was related to performance in the test system. 


\section{Flow and Velocity Measurements}

Flow through the screens was estimated by measuring flow over a weir at the end of the flume (Clay 1961) behind the drum screen. Total flow through the screen was maintained at 1.5 to $2.0 \mathrm{cfs}$. The target flow for the test series was $2.0 \mathrm{cfs}$. However, the large volume of water passing through the bypass when the 6-in. orifice was in use exceeded the system's pumping capacity.

Flow through the fish bypass was estimated by computing the cross-sectional area of the bypass pipe discharge and measuring velocity with a Marsh McBimey Model $2000^{\circledR}$ velocity meter, or by measuring the water depth in the pipe and calculating flow by the California pipe method (Grant 1992). Bypass flows were also confirmed in a separate test series by monitoring the length of time required for the bypass flow to fill a garbage can.

Approach and sweep velocity measurements were taken in front of the drum screen and in the entrance to the fish bypass slot with a Marsh McBimey Model $511^{\circledR}$ bi-directional velocity meter. Electromagnetic "noise" caused by the movement of screen components interfered with our ability to make measurements during actual tests. However, flow patterns and water velocities in the test system could be accurately measured if the paddle wheel and drum rotation were temporarily stopped. Flow mapping was completed as a separate task.

\section{Monitoring Fish Behavior with Underwater Video}

In some tests, fish behavior was monitored in front of the drum screens and as fish exited through submerged orifices with an underwater video camera. The underwater video system consisted of a high-sensitivity remote camera (Sony, model HVM-352 ${ }^{\circledR}$ ) with a wide angle lens (70" Sony, model VCL-06HS ${ }^{\circledR}$ ) encased in a water resistant case (Sony, model WPC-140 ${ }^{\circledR}$ ) and connected by $66 \mathrm{ft}$ of quadraxial cable to an 8-mm camcorder (Sony, model CCD-FX710 Handycam $\left.\mathrm{Hi}^{(}{ }^{\circledR}\right)$ in a weatherproof housing. The underwater camera can operate at extremely low light levels (<1 lux), and artificial light sources were not needed to obtain sharp video images during daylight hours. 


\section{Results}

Passage rates were measured during each test to compare the effectiveness of the three bypass configurations. A 12-test series ( 3 bypass types $\mathrm{x} 4$ replicates) was completed with spring chinook salmon fry/fingerlings (45-60 mm FL) and subyearlings (90-1 $10 \mathrm{~mm} \mathrm{FL).} \mathrm{A} \mathrm{9-test}$ series ( 3 bypass types x 3 replicates) was completed with smolts (120-180 mm FL). The fry/fingerlings tests were conducted from February through early March 1994 at a test temperature of $10 \pm 1^{\circ} \mathrm{C}$. Subyearling tests were conducted in June 1994 at a temperature of $17 \pm 1^{\circ} \mathrm{C}$. Smolt tests were completed in April 1995 at a temperature of $9.5 \pm 1^{\circ} \mathrm{C}$.

\section{Passage Rate}

There was no significant difference in passage related to bypass configuration for spring chinook salmon fry/fingerlings (Table 1). The length of time for $50 \%$ of the fish to exit was between 4 and $8 \mathrm{hr}$ for each of the three bypass configurations. Variability in movement behavior among replicates of the same configuration was higher than among the different configurations (Figure 4). For example, fish movement was fastest during the first hr in the first two replicates with the weir in the bypass (41 and 48 fish out of 100), but slower during the last two replicates (6 and 19 fish out of 100). In general, most fish moved through the bypass either within the first $2 \mathrm{hr}$ or at sundown. Few fish exited after the first $24 \mathrm{hr}$ (Figure 5). The number of fish remaining in the forebay (residuals) ranged from $17 \%$ to $42 \%$ after $24 \mathrm{hr}$, and from $11 \%$ to $23 \%$ in tests that ran $48 \mathrm{hr}$.

Table 1. Number of Fry/Fingerling Spring Chinook Salmon that Moved Through the Bypass During Sample Intervals in Orifice Tests with a Modular Fish Screen, Spring 1994

\begin{tabular}{|c|c|c|c|c|c|c|c|c|c|c|c|c|c|c|c|}
\hline \multirow[b]{2}{*}{ Interval } & \multicolumn{5}{|c|}{$\begin{array}{l}2 \text { in. Orifice } \\
\text { Test Number }\end{array}$} & \multicolumn{5}{|c|}{$\begin{array}{l}6 \text { in. Orifice } \\
\text { Test Number }\end{array}$} & \multicolumn{5}{|c|}{$\begin{array}{l}\text { Weir } \\
\text { est Number }\end{array}$} \\
\hline & 1 & 2 & 3 & 4 & Ave. & 1 & 2 & 3 & 4 & Ave. & 1 & 2 & 3 & 4 & Ave. \\
\hline $1 \mathrm{hr}$ & 22 & 15 & 28 & 24 & 22.25 & 29 & 7 & 38 & 34 & 27.0 & 41 & 48 & 6 & 19 & 28.5 \\
\hline $2 \mathrm{hr}$ & 14 & 11 & 10 & 18 & 13.25 & 12 & 7 & 9 & 13 & 10.25 & 12 & 8 & 1 & 5 & 6.5 \\
\hline $4 \mathrm{hr}$ & 11 & 12 & 7 & 13 & 10.75 & 17 & 5 & 6 & 4 & 8.0 & 6 & 8 & 12 & 3 & 7.25 \\
\hline $8 \mathrm{hr}$ & 19 & 29 & 23 & 10 & 20.25 & 8 & 49 & 12 & 6 & 18.75 & 18 & 10 & 23 & 24 & 18.75 \\
\hline $24 \mathrm{hr}$ & 7 & 7 & 10 & 18 & 10.5 & 6 & 9 & 4 & 6 & 6.25 & 3 & 2 & 19 & 7 & 7.75 \\
\hline $48 \mathrm{hr}$ & 10 & 3 & - & - & 6.5 & 8 & 0 & - & - & 4.0 & 7 & 13 & - & - & 10.0 \\
\hline Total & 83 & 77 & 78 & 83 & & 80 & 77 & 69 & 63 & & 87 & 89 & 61 & 58 & \\
\hline
\end{tabular}




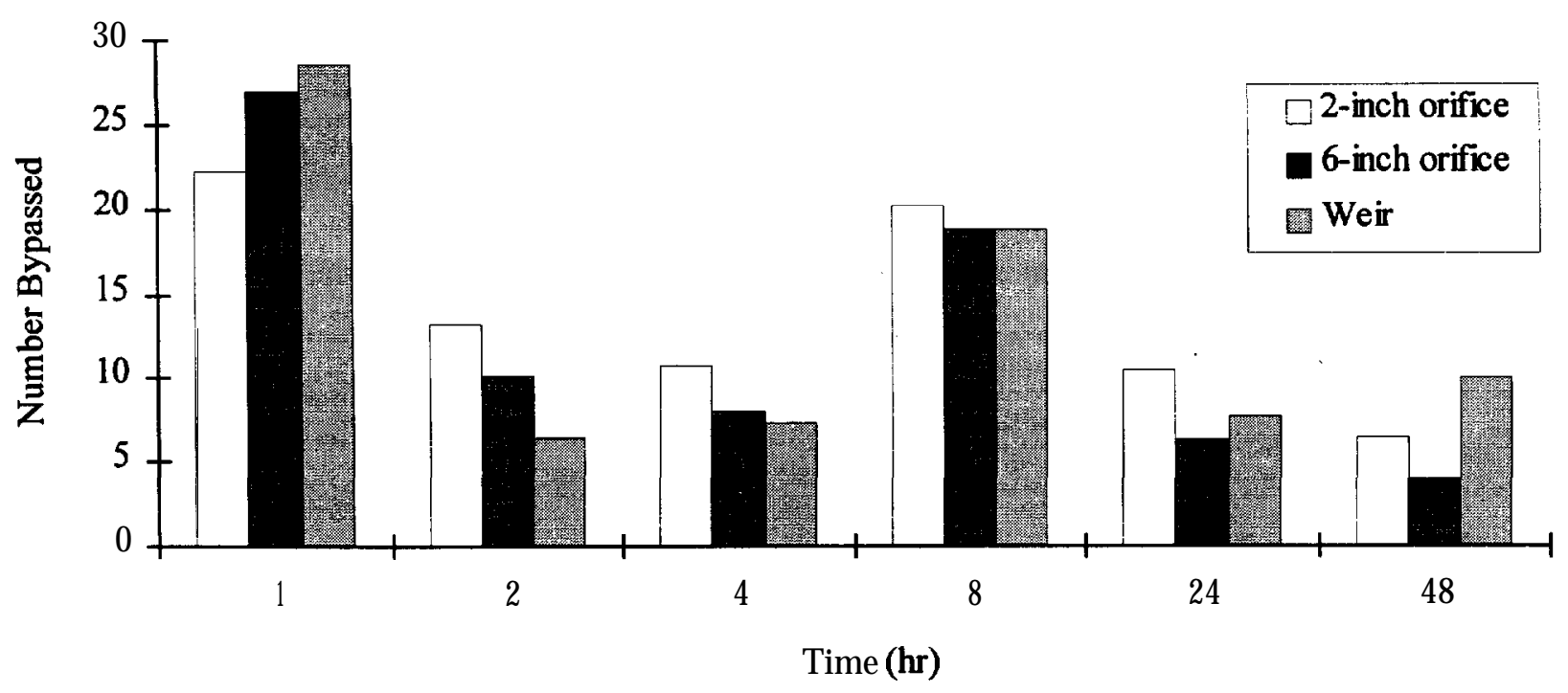

Figure 4. Movement of Fry Spring Chinook Salmon by Sampling Interval During In Vivo Tests with a Modular Fish Screen, Spring 1994

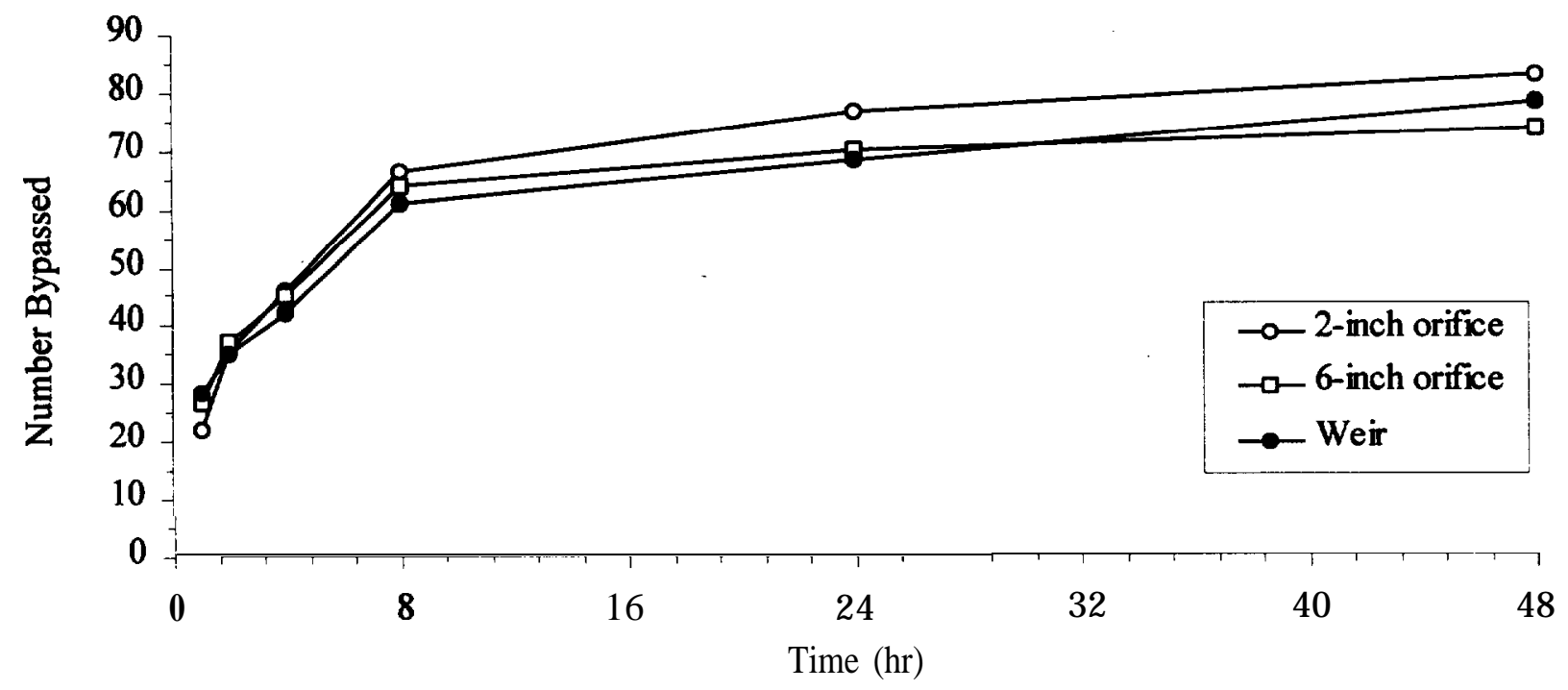

Figure 5. Cumulative Recovery of Fry Spring Chinook Salmon During In Vivo Tests with a Modular Fish Screen, Spring 1994 
Following release fry/fingerling spring chinook salmon quickly dispersed throughout the forebay area. Most fish quickly located and entered the bypass slot but did not immediately exit through the bypass. After discovering the bypass location, many fish returned to the screens forebay and milled around. Some fish entered and exited the fish bypass slot several times. Eventually, fish stayed in the fish bypass slot, facing into the bypass flow, for up to several hours before exiting through the fish bypass.

In tests with the 2-in. orifice, chinook salmon fry/fingerlings were able to hold their position within about two body lengths (- 4 in.) in front of the orifice with minimal swimming activity. Fish that came within a body length of the orifice opening usually could not escape and were swept through the orifice. Most fish exited tail-first, although some fish passed through the orifice head-first or sideways.

The abrupt change in cross-sectional area from the 2-in. orifice to an 8-in. pipe caused cavitation to occur at the orifice opening. Cavitation may have benefited fish during passage by creating an "air pillow" around the perimeter of the orifice that helped to "center" fish as they passed through the orifice. Few fry/fingerlings came into contact with the edges or comers of the orifice during passage.

In tests with the 6-in. orifice, fry/fingerlings detected the bypass flow at the entrance to the fish return slot. Increased flow and velocity caused some fish to avoid entering the bypass slot initially. With time, fish accepted the velocity conditions and entered the bypass slot. Fish within about 5 body lengths $(-1 \mathrm{ft})$ had to swim vigorously to avoid being involuntarily swept through the orifice. As with the 2-in. orifice, most fish oriented into the current and fell back to exit through the 6-in. orifice. Most fish exhibited avoidance behavior (intermittently darting away from the orifice opening) before exiting tail-first, although some fish exited head-first or sideways.

In tests with the overflow weir, fry/fingerlings quickly located the fish bypass slot, but frequently held in the bypass slot or returned to the screen forebay before attempting to exit over the weir. Behavior of fish as they exited over the weir was difficult to observe with underwater video because positioning the camera in the bypass slot interfered with fish movement. Based on limited observations, it appeared that most fish exited over the weir tail-first.

Subyearlings preferred the large orifice and exited sooner and at a higher rate than when the small orifice or weir were used in the fish bypass (Table 2). The length of time for $50 \%$ of the fish to exit was between 4 and $8 \mathrm{hr}$ when the 6-in. orifice was used, and from 8 to $24 \mathrm{hr}$ when the 2-in. orifice or weir was used. The biggest difference in movement occurred during the first hour after the test fish were released (Figure 6). The cumulative passage rate over a 48-hr period also showed a preference for the large orifice (Figure 7). Movement of subyearling salmon over the weir was slow during the daytime, with most movement occurring at sundown or overnight. Subyearling remaining in the forebay (residuals) ranged from $15 \%$ to $64 \%$ after $24 \mathrm{hr}$ and from $11 \%$ to $49 \%$ after $48 \mathrm{hr}$. 
Table 2. Number of Subyearling Spring Chinook Salmon that Moved Through the Bypass During Sample Intervals in Orifice Tests with a Modular Fish Screen, Spring 1994

\begin{tabular}{|c|c|c|c|c|c|c|c|c|c|c|c|c|c|c|c|}
\hline & \multicolumn{5}{|c|}{$\frac{2 \text {-in. Orifice }}{1}$} & \multicolumn{5}{|c|}{$\begin{array}{l}\text { 6-in. Orifice } \\
\text { Test Number }\end{array}$} & \multicolumn{5}{|c|}{$\begin{array}{c}\text { Weir } \\
\text { Test Number }\end{array}$} \\
\hline Interval & 1 & 2 & 3 & 4 & Ave. & 1 & 2 & 3 & 4 & Ave. & 1 & 2 & 3 & 4 & Ave. \\
\hline $1 \mathrm{hr}$ & 3 & 22 & 3 & 17 & 11.25 & 35 & 16 & 12 & 25 & 22.0 & 3 & 2 & 1 & 16 & 5.5 \\
\hline $2 \mathrm{hr}$ & 1 & 3 & 7 & 9 & 5.0 & 5 & 8 & 5 & 14 & 8.0 & 0 & 2 & 1 & 3 & 1.5 \\
\hline $4 \mathrm{hr}$ & 9 & 5 & 8 & 10 & 8.0 & 9 & 9 & 15 & 15 & 12.0 & 2 & 7 & 1 & 2 & 3.0 \\
\hline $8 \mathrm{hr}$ & 15 & 14 & 14 & 14 & 14.25 & 17 & 14 & 33 & 16 & 20.0 & 11 & 44 & 34 & 36 & 31.25 \\
\hline $24 \mathrm{hr}$ & 17 & 17 & 24 & 14 & 18.0 & 10 & 18 & 20 & 11 & 14.75 & 20 & 14 & 18 & 28 & 20.0 \\
\hline $48 \mathrm{hr}$ & 17 & 8 & 14 & 21 & 15.0 & 8 & 17 & 8 & 10 & 10.75 & 15 & 6 & 12 & 4 & 9.25 \\
\hline Total & 62 & 69 & 70 & 85 & 71.5 & 84 & 82 & 93 & 91 & 87.5 & 51 & 75 & 67 & 89 & 70.5 \\
\hline
\end{tabular}

The behavior and reactions of subyearling spring chinook salmon were similar to those of fry/fingerling salmon. Subyearlings quickly found the bypass slot but most chose to hold in the screens forebay during the day. Subyearling chinook salmon could easily hold in front of the 2 -in. orifice and could maintain their position within $1 \mathrm{ft}$ of the 6-in. orifice. Although it appeared that many subyearling salmon came in contact with the sides of the 2 -in. orifice during passage, partial descaling or other injuries were rare.

Movement of subyearling salmon over the weir was infrequent during the daytime, especially on bright, sunny days. Subyearling fish tended to stay near the bottom of the forebay and fish bypass slot. Placing a shade over the fish bypass on sunny days did not appear to enhance movement rate or bypass use.

In contrast to tests with fingerlings and subyearlings, movement of spring chinook salmon smolts from the screens forebay was very rapid (Table 3). The length of time for $50 \%$ of the fish to exit was less than $0.25 \mathrm{hr}$ with the 6-in. orifice, $0.5 \mathrm{hr}$ with the weir, and about $1 \mathrm{hr}$ with the 2-in. orifice (Figure 8). Movement activity increased at sunset in tests with the 2-in. orifice and weir. The number of smolts remaining in the forebay (residuals) ranged from 0 to $7 \%$ after 24 hours, with most of the residualism occurring when the 2-in. orifice was used (Figure 9). Residual fish were generally smaller and did not display strong signs of smoltification. Although some fish hesitated for a short time before passage, many fish exited immediately. Smolts usually passed through the 2-in. orifice tail first. Many smolts came in contact with the sides of the 2-in orifice, but few injuries occurred. Salmon smolts went through the 6-in. orifice tail-first, head-first, and sideways. Movement over the weir was usually tail-first. Smolts did not appear hesitant about migrating over the weir during the daytime, even under bright, sunny conditions. 


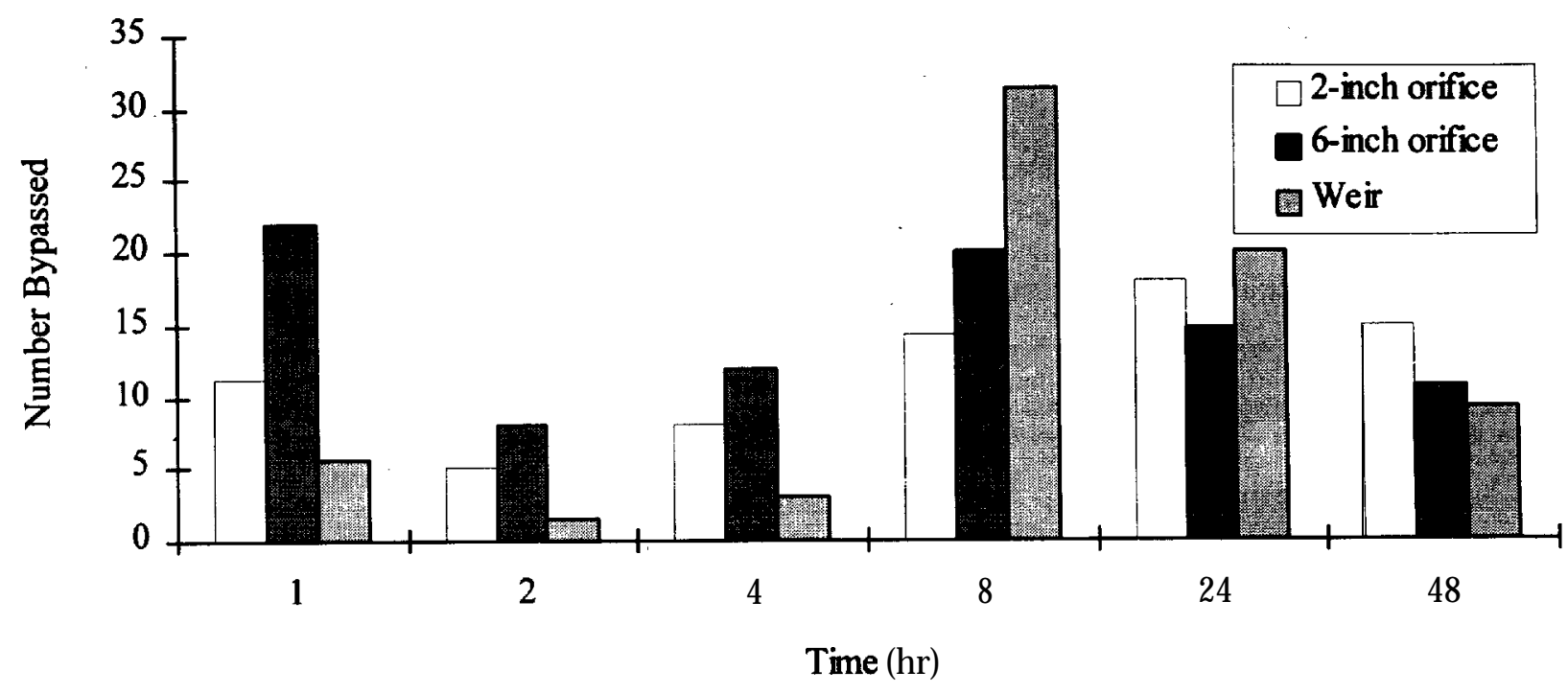

Figure 6. Movement of Subyearling Spring Chinook Salmon by Sampling Interval During In Vivo Tests with a Modular Fish Screen, Spring 1994

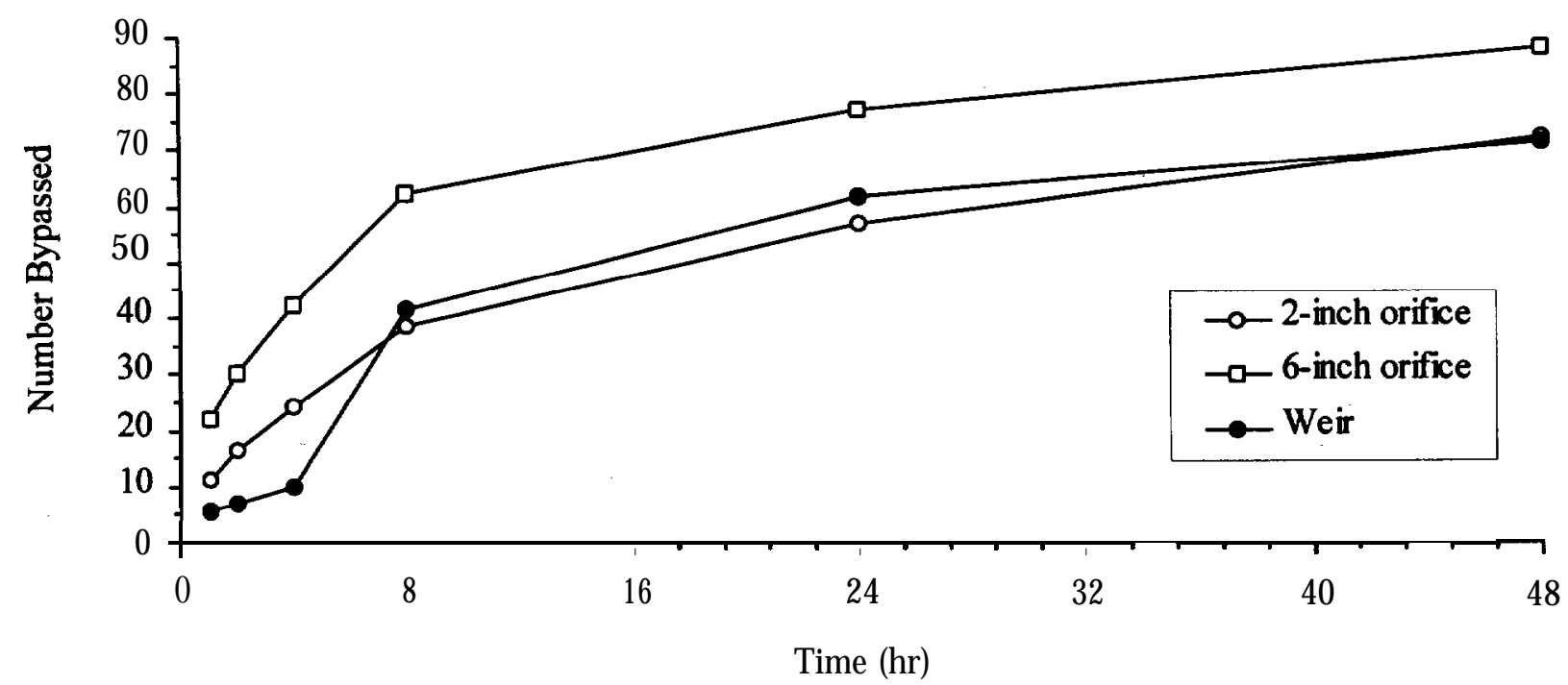

Figure 7. Cumulative Recovery of Subyearling Spring Chinook Salmon During In Vivo Tests with a Modular Fish Screen, Spring 1994 
Table 3. Number of Smolt Spring Chinook Salmon that Moved Through the Bypass During Sample Intervals in Orifice Tests with a Modular Fish Screen, Spring 1995.

\begin{tabular}{|ccccc|cccc|cccc|}
\hline \multicolumn{4}{|c|}{ 2 in. Orifice } & \multicolumn{3}{c|}{ 6-in. Orifice } & \multicolumn{3}{c|}{ Weir } \\
\multicolumn{3}{|c}{ Test Number } & \multicolumn{3}{c|}{ Test Number } & \multicolumn{3}{c|}{ Test Number } \\
\hline Interval & 1 & 2 & 3 & Ave. & 1 & 2 & 3 & Ave. & 1 & 2 & 3 & Ave. \\
\hline $0.25 \mathrm{hr}$ & 35 & 17 & 4 & 18.7 & 65 & 53 & 35 & 51.0 & 48 & 9 & 17 & 24.7 \\
$0.5 \mathrm{hr}$ & 26 & 14 & 23 & 21.0 & 25 & 38 & 16 & 26.3 & 33 & 37 & 26 & 32.0 \\
$0.75 \mathrm{hr}$ & 7 & 8 & 13 & 9.3 & 5 & 5 & 18 & 9.3 & 8 & 10 & 20 & 12.7 \\
$1 \mathrm{hr}$ & 4 & 5 & 8 & 5.7 & 1 & 1 & 11 & 4.3 & 2 & 4 & 13 & 6.3 \\
$2 \mathrm{hr}$ & 5 & 17 & 3 & 8.3 & 2 & 1 & 10 & 4.3 & 7 & 7 & 22 & 12.0 \\
$4 \mathrm{hr}$ & 4 & 15 & 5 & 8.0 & 0 & 1 & 9 & 3.3 & 1 & 5 & 1 & 2.3 \\
$8 \mathrm{hr}$ & 12 & 8 & 19 & 13.0 & - & - & - & - & & 20 & - & 6.7 \\
$24 \mathrm{hr}$ & 2 & 6 & 18 & 8.7 & 2 & 1 & 0 & 1.0 & 1 & 4 & 1 & 2.0 \\
Total & 95 & 90 & 93 & 92.7 & 100 & 100 & 99 & 99.7 & 100 & 96 & 100 & 98.7 \\
\hline
\end{tabular}

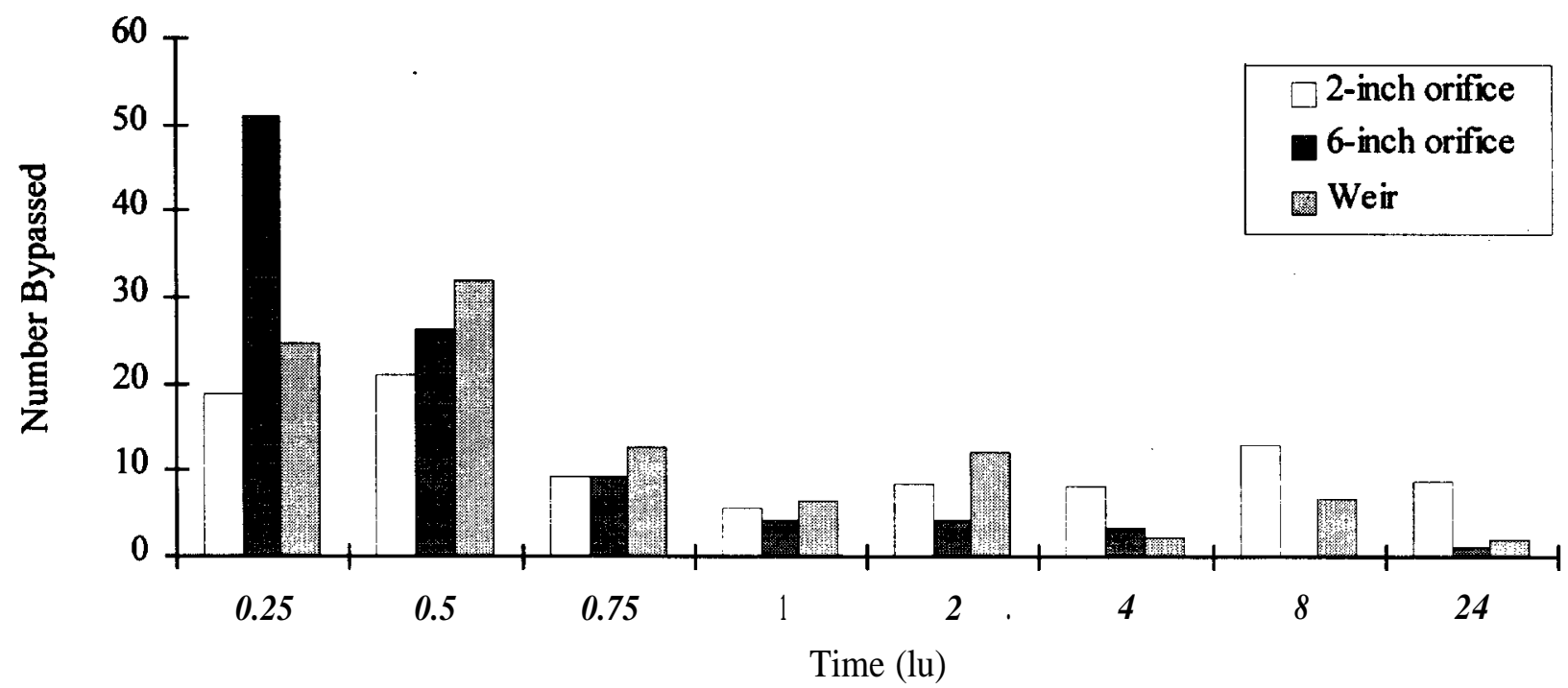

Figure 8. Movement of Smolt Spring Chinook Salmon by Sampling Interval During In Vivo Tests with a Modular Fish Screen, Spring 1995 


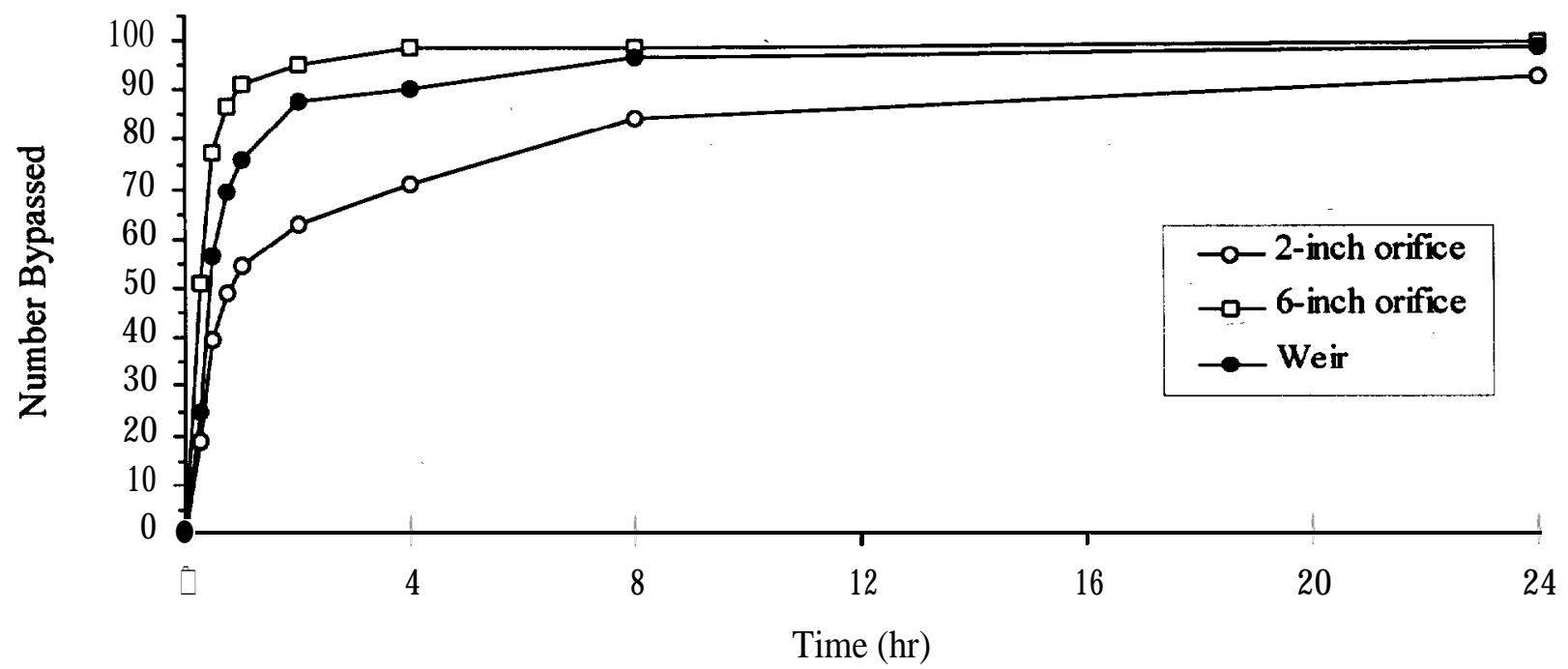

Figure 9. Cumulative Recovery of Smolt Spring Chinook Salmon During In Vivo Tests with a Modular Fish Screen, Spring 1995

\section{Statistical Analysis}

The results from the ANOVA (Table 4) indicate that there were significant differences in passage rate $(\mathrm{p} \leq 0.05)$ among the bypass configurations for smolts, moderately significant differences $(0.05 \leq \mathrm{p} \leq 0.10)$ among the sub-yearlings and no significant differences among the fry $(p>0.10)$. Between group variance was greater than the within group variance for the smolts and subyearlings. Between group variance was less than the within group variance for the fry. The outcome for the sub-yearlings is close to being statistically significant at the $5 \%$ significance level suggesting that variances were affected by biological factors.

Tukey's multiple comparison (Table 5) indicated no significant difference between orifices for chinook fry and chinook sub-yearlings at $1 \mathrm{hr}$ and $8 \mathrm{hr}$ intervals $(\mathrm{p} \leq 0.05)$. A significant difference existed between the 2 -in. and the 6 -in. orifice $(P \leq 0.05)$ for the smolts at the $1 \mathrm{hr}$ interval as well as the $8 \mathrm{hr}$ interval. Fewer smolts passed through the 2 -in. orifice (164 at $1 \mathrm{hr}$ and 252 at $8 \mathrm{hr}$ ) than the 6-in. orifice (273 at $1 \mathrm{hr}$ and 296 at $8 \mathrm{hr}$ ). The movement through the orifices was more pronounced and occurred over a shorter period of time for the smolts than for the other life stages of chinook salmon.

Tukey's multiple comparison analysis indicated a moderately significant difference $(\mathrm{p} \leq 0.1)$ between the 2-in. and the 6-in. orifice for the $8 \mathrm{hr}$ interval for subyearlings (Table 6). Fewer subyearlings (154 at $8 \mathrm{hr}$ ) passed through the 2 -in. orifice than the 6 -in. orifice (248 at $8 h r)$. 
Table 4. Single Factor ANOVA for Spring Chinook Fry, Subyearlings, and Smolts Comparing the Three Different Bypass Configurations: 2-in. Orifice, 6-in. Orifice and Overflow Weir at 1 and $8 \mathrm{hr}$

\begin{tabular}{|l|c|l|l|}
\hline & & \multicolumn{2}{|c|}{ P value } \\
\hline \hline & $d f$ & $1 \mathrm{hr}$ & $8 \mathrm{hr}$ \\
\hline Fry & & & \\
Sub-yearlings & 11 & $0.81 \mathrm{~ns}^{(\mathrm{a})}$ & $0.759 \mathrm{~ns}$ \\
Smolt & 11 & $0.081^{(\mathrm{b})}$ & $0.077^{(\mathrm{b})}$ \\
\hline
\end{tabular}

(a) $\mathrm{ns}=$ not significant

(b) moderately significant $(0.05 \leq \mathrm{p} \leq 0.10)$

(c) significant $(\mathrm{p} \leq 0.05)$

Table 5. Tukey's Multiple Comparison at $\mathrm{P} \leq 0.05$ (CI $=$ Confidence Interval). Only CI results that are significant, comparisons that have $\mathrm{CI}$ 's $<$ difference of averages, are reported in the table below.

\begin{tabular}{|c|ccccc|}
\hline Comparison & Period & Fry & Subyearling & Smolt \\
\hline 6-in. vs 2-in. orifice & $1 \mathrm{hr}$ & $\mathrm{ns}^{(\mathrm{a})}$ & $\mathrm{ns}$ & $36.33 \pm 31.25 \mathrm{CI}$ \\
& $\mathbf{8 ~ h r}$ & $\mathrm{ns}$ & $\mathrm{ns}$ & $14.67 \pm 13.05 \mathrm{CI}$ \\
\hline 6-in. orifice vs weir & $1 \mathrm{hr}$ & $\mathrm{ns}$ & $\mathrm{ns}$ & $\mathrm{ns}$ \\
& $\mathbf{8 ~ h r}$ & $\mathrm{ns}$ & $\mathrm{ns}$ & $\mathrm{ns}$ \\
\hline 2 -in orifice. vs weir & $1 \mathrm{hr}$ & $\mathrm{ns}$ & $\mathrm{ns}$ & $\mathrm{ns}$ \\
& $\mathbf{8 ~ h r}$ & $\mathrm{ns}$ & $\mathrm{n} \mathrm{s}$ & $\mathrm{ns}$ \\
\hline
\end{tabular}

(a) $\mathrm{ns}=$ not significant 
Table 6. Tukey's Multiple Comparison at $\mathbf{P} \leq 0.10(\mathrm{CI}=$ Confidence Interval). Only CI results that are significant, comparisons that have CI's $<$ difference of averages, are reported in the table below.

\begin{tabular}{|ccccc|}
\hline Comparison & Period & Fry & Subyearling & Smolt \\
\hline 6-in. orifice vs & $1 \mathrm{hr}$ & $\mathrm{ns}^{\text {(a) }}$ & $\mathrm{ns}$ & $\mathbf{3 6 . 3 3 \pm 2 6 . 2 7 \mathrm { CI }}$ \\
2-in. orifice & $\mathbf{8 ~ h r}$ & $\mathrm{ns}$ & $23.5 \mathrm{k} 22.9 \mathrm{CI}$ & $\mathbf{1 4 . 6 7 \pm 1 0 . 9 6 \mathrm { CI }}$ \\
\hline 6-in. orifice vs weir & $1 \mathrm{hr}$ & $\mathrm{ns}$ & $16.5 \mathrm{k} 15.1 \mathrm{CI}$ & $\mathrm{ns}$ \\
& $8 \mathrm{hr}$ & $\mathrm{ns}$ & $\mathrm{ns}$ & $\mathrm{ns}$ \\
\hline 2-in. orifice vs weir & $1 \mathrm{hr}$ & $\mathrm{ns}$ & $\mathrm{ns}$ & $\mathrm{ns}$ \\
& $8 \mathrm{hr}$ & $\mathrm{ns}$ & $\mathrm{ns}$ & $\mathbf{1 2 . 6 7 \pm 1 0 . 9 6 \mathrm { CI }}$ \\
\hline
\end{tabular}

(a) $\mathrm{ns}=$ not significant

\section{Fish Injury}

Of the approximately 1200 fish examined in the fry/fingerling test series, we observed only 1 fish with injuries that were not attributable to handling. Partial descaling was observed on some fish $(<1 \%)$, but the low incidence of descaling did not appear to be related bypass configuration. Of the almost 1200 fish examined in the subyearling series, 5 fish ( 3 fish passing through the large orifice and 2 fish passing through the small orifice) had moderate descaling. Other fish had very light descaling, but the incidence of minor descaling was not closely documented. In one test with the 2-in. orifice, 2 fish with discoloration (bruising) around an eye were observed, but the injuries may have been caused by netting the fish from the live box. Overall, the number of injuries observed in test fish was very small.

In the smolt series, fish passing through the 2-in. orifice displayed a significantly higher incidence of light to moderate descaling, although very few fish had scale loss severe enough to classify them as descaled with the criteria established for evaluating the condition of fish in smolt bypass systems at dams on the Columbia and Snake Rivers (Basham et al. 1982). Estimates for the percentage of fish partially descaled depended on the number of fish examined. The lower and upper confidence intervals (LCI and UCI, respectively) were estimated as

$$
L C I=\frac{B}{B+(n-B+1) F}
$$

and

$$
\mathrm{UCI}=1-\frac{n-B}{n-B[n-(n-B)+1] F}
$$


where

$$
\begin{aligned}
\mathrm{B}= & \text { the number of partially descaled fish } \\
\mathrm{n}= & \text { the number of fish examined, and } \\
\mathrm{F}= & \text { the ratio of the estimates for the mean sample } \\
& \text { variance and the individual sample variance. The } \\
& \text { estimates were calculated from Mainland's Tables } \\
& \text { (Mainland et al. 1956). }
\end{aligned}
$$

When compared to the baseline condition of the test stock, about $15 \%$ more fish passing through the 2-in. orifice one time were partially descaled (Table 7). Descaling was often in the form of a vertical "scratch." Many of the scratches ended in a crescent-shaped arch above the lateral line. This type of descaling pattern is consistent with the type of injury that could occur if a fish was impinged across the orifice opening. With an underwater video camera, we observed that as much as $50 \%$ of smolts passing through the 2-in. orifice made significant contact with the sides of the orifice. Some fish displayed less defined "patchy" descaling. A few fish had discoloration or "bruises," usually in the area just posterior to the operculum.

Table 7. Estimate of Partial Descaling Rate for Smolt Spring Chinook Salmon After Passing Through the Fish Bypass in a Modular Fish Screen

\begin{tabular}{|lcccc|}
\hline & Number & \multicolumn{2}{c}{ Partially Descaled } & 95\% Confidence \\
\cline { 3 - 4 } Test Croup & Examined & Number & Percent & Interval (\%) \\
\hline Control fish & 100 & 10 & 10.0 & $4.9-17.6$ \\
2-in. orifice & 278 & 72 & 25.9 & $20.9-\mathbf{3 1 . 6}$ (a) $^{\text {(n) }}$ \\
6-in. orifice & 299 & 30 & 10.0 & $6.9-14.0$ \\
Weir & 296 & 24 & 8.1 & $5.2-11.6$ \\
\hline
\end{tabular}

(a) significant $(\mathrm{p} \leq 0.05)$

\section{Entrainment}

Spring chinook salmon fry, subyearling, and smolts did not pass over, around, or through the drum screen during our tests. Of the 3300 fish used, only six fish were not accounted for as either successfully bypassed or residual fish. During some tests, a few fish that either escaped from the live box or jumped over the diffiser screen from the forebay area were recovered from the head box at the end of a test. However, when the forebay and live box were covered to prevent escape, the incidence of "missing" fish dropped to near zero. 


\section{Flow and Velocity}

Flow through the fish screen was identical during each test series. Flow was set by placing a weir either in front of or behind the paddle wheel and maintaining the desired drum screen submergence (75\%-87\%). Submergence level was set by adjusting a valve on the water supply line to compensate for the differences in the quantity of water passing through each of the three bypass configurations.

Bypass flow was monitored during tests by measuring the depth of the water at the terminus of the fish bypass pipe. Bypass flow was affected by water depth (head) in the fish bypass, the cross-sectional area of the submerged orifice, or height of the bypass weir, depending on which bypass configuration was in use. Bypass flows, as measured at the end of the bypass pipe, were very consistent for each orifice configuration. At the end of the test series, bypass flow was verified with three methods of measurement (Table 8). The three methods gave very similar values for bypass flow estimates.

Water velocity profiles in front of the screens, in the forebay, and in the fish bypass were completed with a bi-directional current meter. Approach (X component) and sweep (Y component) velocities were recorded and the resultant vectors were computed to develop flow maps. When the 2-in. orifice was used (Figure 10), approach velocity was relatively uniform at the face of the drum screen. However, attraction flow (sweep velocity towards the fish bypass) was poor at both 0.2 and 0.8 of the depth due to the small bypass flow.

When the 6-in. orifice was used, bypass flow was equal to or greater than flow through the drum screen. Approach velocity exceeded the $0.4 \mathrm{fps}$ criteria in the center of the screen (Figure 11). An eddy or dead spot in front of the screen on the side opposite the fish bypass contributed to the imbalanced flow through the screen. Attraction flow to the fish bypass was evident in the screen forebay at 0.8 of the depth, and sweep velocity in the fish bypass slot was $1.0 \mathrm{fps}$.

Table 8. Comparison of Bypass Flow Through Different Bypass Configurations Using Three Measurement Methods

\begin{tabular}{|c|c|c|c|}
\hline Method & 2-in. Orifice & 6-in. Orifice & Weir (0.375 ft head) \\
\hline Stopwatch/Bucket & $0.25 \mathrm{cfs}$ & $\sim 1.6 \mathrm{cfs}$ (a) & $0.70 \mathrm{cfs}$ \\
Area/Velocity (Q=AV) & $0.23 \mathrm{cfs}$ & $1.63 \mathrm{cfs}$ & $0.78 \mathrm{cfs}$ \\
California Pipe Method & $0.24 \mathrm{cfs}$ & $2.04 \mathrm{cfs}$ & $0.68 \mathrm{cfs}$
\end{tabular}

(a) Questionable measurement estimate because 21-gal barrel filled very quickly and it was difficult to determine when container was filled to overflowing. 


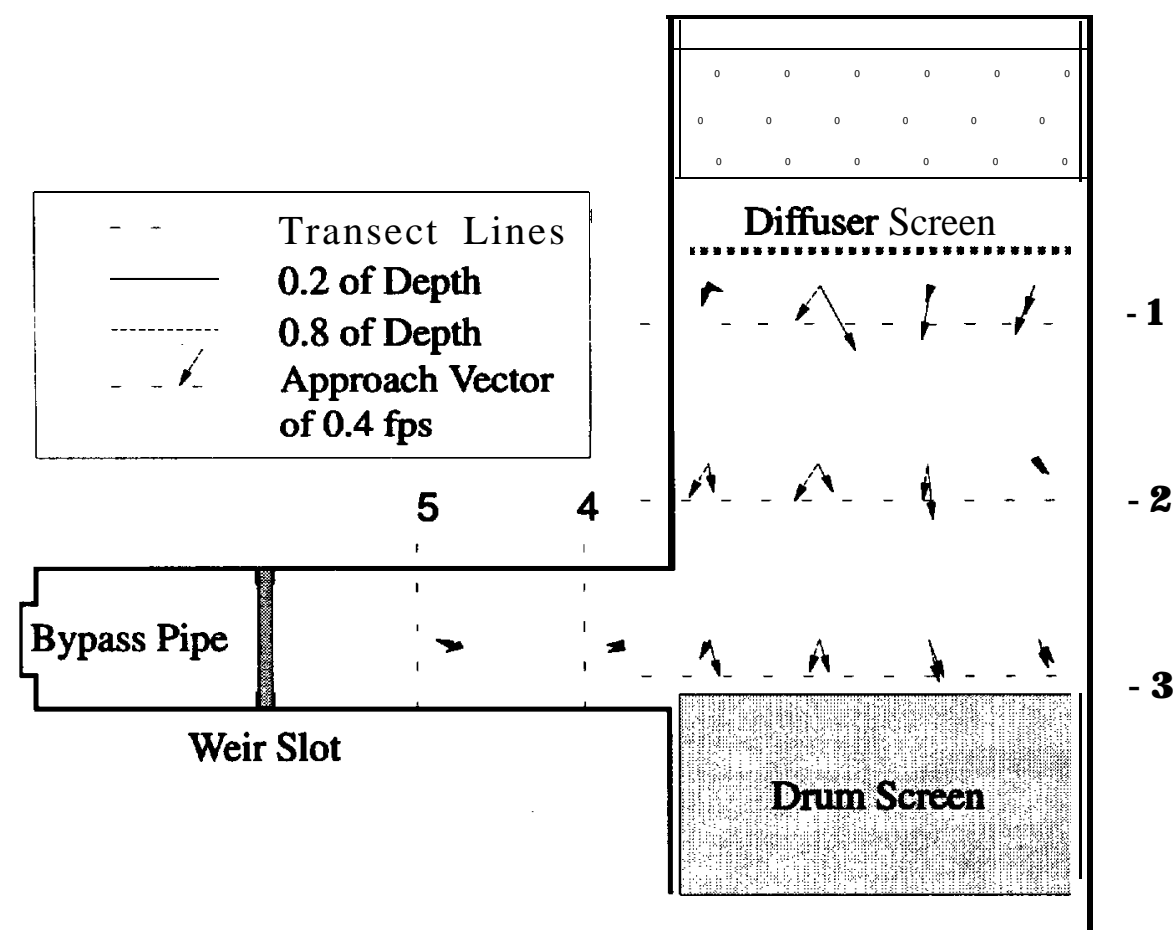

Figure 10. Velocity Profile in Front of the Drum Screen and in the Fish Bypass Slot with a 2-in. Orifice Used for Fish Bypass

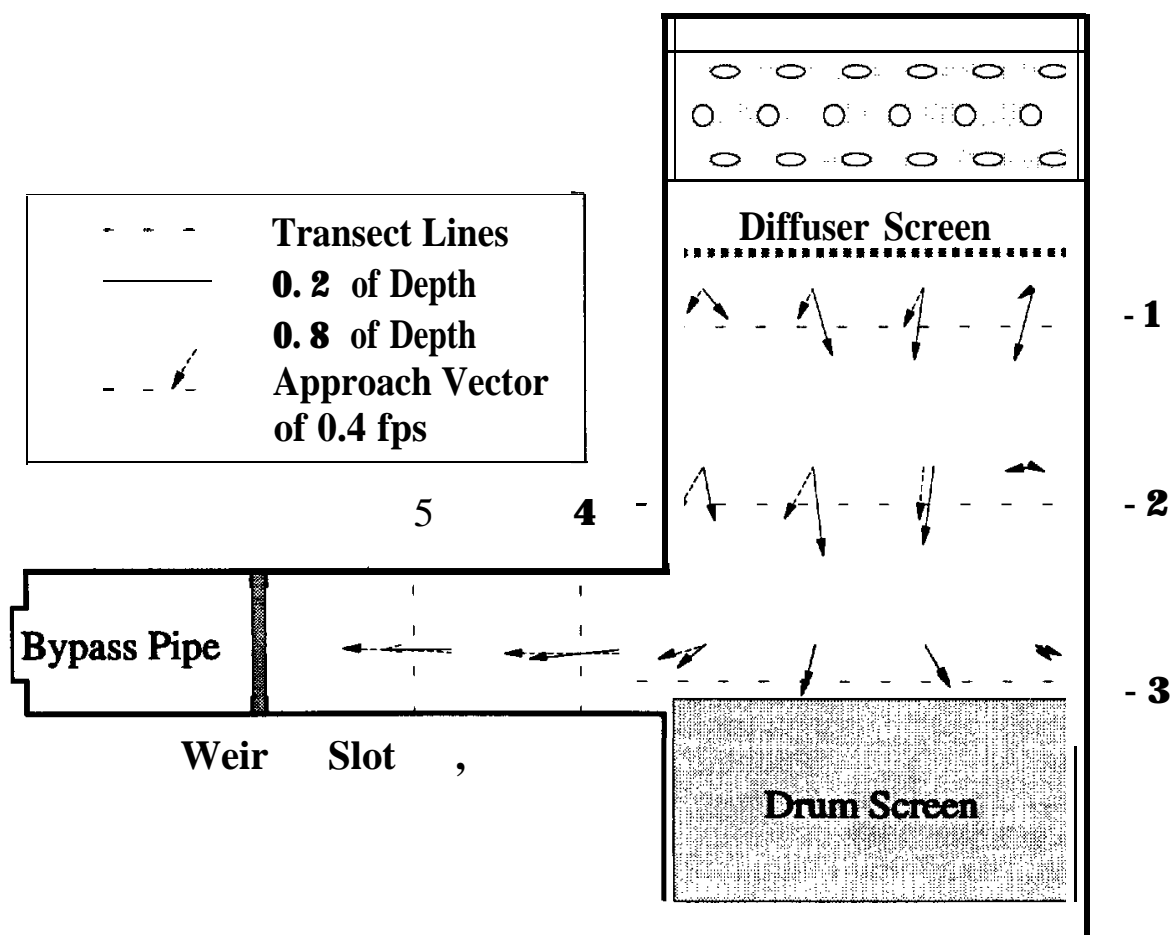

Figure 11. Velocity Profile in Front of the Drum Screen and in the Fish Bypass Slot with a 6-in. Orifice Used for Fish Bypass 
Flow patterns in front of the screen when a weir was used in the fish bypass were similar to patterns observed when the 6-in. orifice was used. Approach velocity at the face of the drum screen slightly exceeded the $0.4 \mathrm{fps}$ guideline in the center of the screen, and a dead spot occurred in front of the drum screen in the comer opposite the fish return (Figure 12). Sweep velocity in the fish bypass was about $0.75 \mathrm{fps}$. Although a weir would seem to draw water from the surface, attraction flow did not occur at 0.2 of the depth, but was evident at 0.8 of the depth midway across the screen forebay.

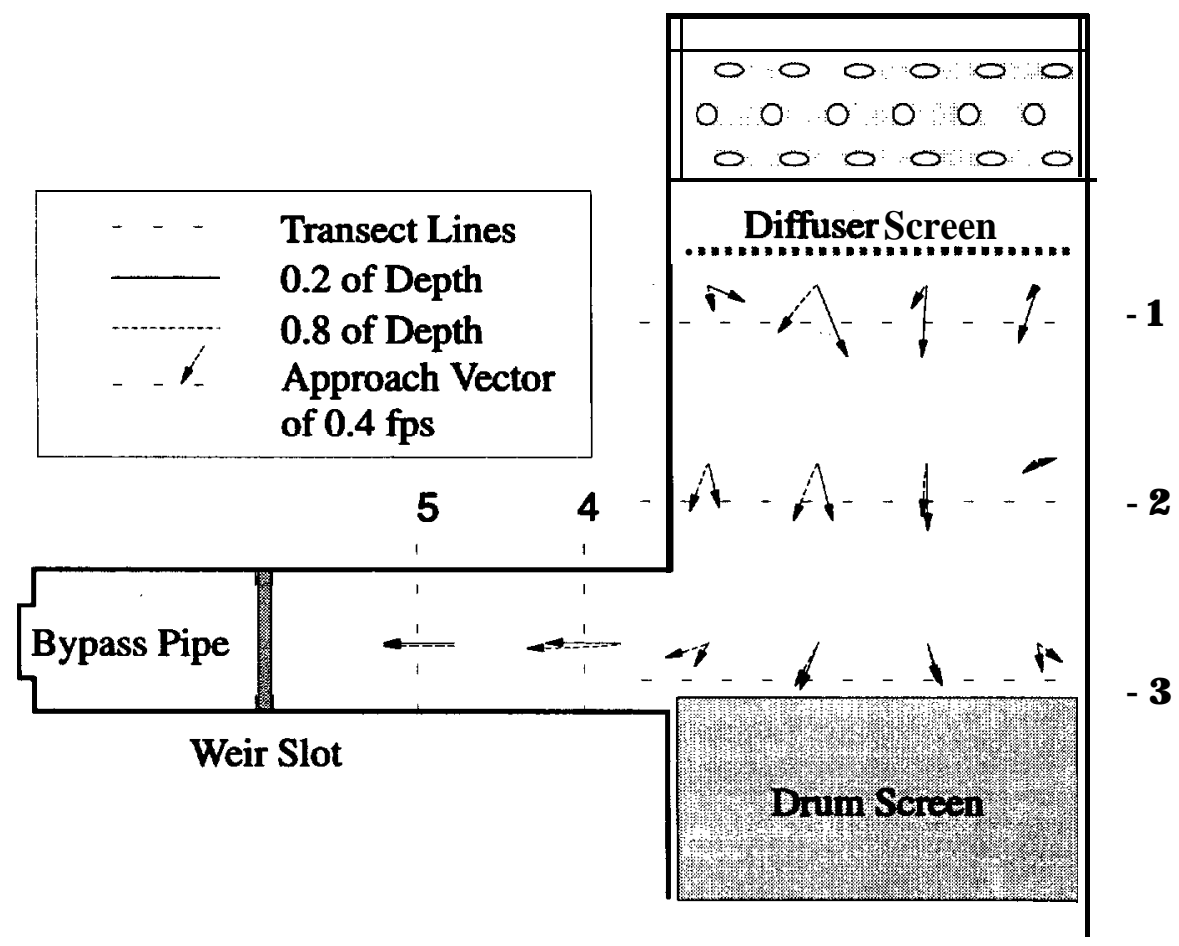

Figure 12. Velocity Profile in Front of the Drum Screen and in the Fish Bypass Slot with a Weir Used for Fish Bypass 


\section{Discussion}

The primary objective of our tests was to compare the effectiveness of two submerged orifices in providing safe, efficient passage for juvenile salmonids. The orifice sizes we tested represent the range of orifices currently used to provide bypass flow at irrigation diversions in the Salmon River Basin, Idaho, including sites on the Lemhi River. The difference in passage rate we observed was related to the fish size relative to the cross-sectional area of the bypass configurations. ANOVA indicated a statistically significant difference in passage rate among the, orifice types (at $\mathrm{P} \leq 0.05$ ) for smolts but not for the fry and subyearlings.

Bjom (1978) identified three major migration periods for juvenile chinook salmon in the upper Lemhi River. Fry emerged in January and February and many moved to downstream rearing areas from March through late May. Smolt-size subyearlings also moved out in September through October. For smolts overwintering in the upper Lemhi River, seaward migration began in March and continued through May.

Operating procedures for new fish screening facilities are written by the National Marine Fisheries Service (NMFS) and they include instructions on when the 6-in. and 2-m. orifices are to be used. The recommendations are based on quantity of water withdrawn, head gate settings, water availability, and the user's legal water entitlement. The procedures generally state that the 6-in. orifice will be used whenever water withdrawal is sufficient to provide the user with his legal entitlement and there is ample water to operate the large orifice. When it is not possible to withdraw enough water to operate the 6-in. orifice without impacting the user's legal entitlement, the 2-in. orifice may be used.

Newly emergent fry and smolts may both be present in the Lemhi River at the beginning of the irrigation season, which starts on April 1 and continues through early October. Based on the passage rates in our tests with spring chinook salmon smolts, use of the 2-in. orifice during April and May could delay passage during the critical period when smolts are actively migrating to the ocean. In our tests, smolts exited from the screens forebay at a faster rate than the fry and subyearlings, and also preferred the larger orifice. Smolts are physiologically ready to migrate downstream towards the ocean and their rapid movement through all the orifice types was indicative of smoltification.

Downstream movement of fry and subyearling salmon to rearing and overwintering areas during the summer and fall months is less critical because the period over which juvenile salmon can arrive at rearing areas is much wider than for physiologically limited smolts. During the majority of the irrigation season, use of the 6-in. orifice may not be necessary to provide effective passage conditions for juvenile salmonids, because movement of subyearlings is minimal from June through August (Bjom 1978). The relationship of fish size to orifice dimension for fry is different than that for smolts and subyearlings because of the small physical size of emergent fry. Chinook fry are physiologically not ready to migrate at this life stage. Since fry do not have their migratory cues activated at this life stage, their observed behavior in 
these tests suggests that their movement is probably related to foraging activites or the search for suitable holding and rearing habitat. Bjom's (1978) observations on movement indicate that fry may remain in a confined rearing area and later migrate at the smolt stage. A possible consequence of this behavior is that chinook salmon fry will be more prone to reside within a canal system than subyearlings and smolts and, therefore, may be more susceptible to problems with high approach velocities (impingement) and screen integrity due to poor screen seals or overtopping. The results of tests with subyearlings were close enough to being statistically significant at the $5 \%$ significance level (at $\mathrm{P} \leq 0.10$ ) to make us realize that variances were in fact different and a biologically significant difference may exist. Subyearlings are physically larger than fry and many migrate downstream to find overwintering habitat. The Tukey method of multiple comparisons indicated a tendency towards preference for the larger orifice size (6-in. vs 2-in.) for subyearlings and smolts. This makes sense biologically, because as the fish grew, there was a tendency towards the larger orifice configuration to accommodate their larger body size.

The orifice gate provide by the IDFG was constructed of 1/8-in. steel plate. The orifices were cut with a band saw, and the edges of the orifices were not rounded or polished. Contact with the sharp edges of the orifice could cause minor descaling or other injuries, especially when large fish attempt to pass through a small orifice. Based on observations made with an underwater video camera, about half of the spring chinook salmon smolts made significant contact as they passed through the 2 -in. orifice, with about $15 \%$ of the smolts experiencing some descaling or other injuries. Construction of orifice gates from thicker materials that can be rounded to eliminate sharp edges would reduce the risk of injury for fish of all sizes.

The high incidence of partial descaling of smolts resulting from a single pass through a 2-in. orifice indicates that smolts may be subject to cumulative effects (descaling or other injury) from passing through many 2-in. orifices during outmigration. Although cumulative effects from multiple passages has not been documented, additional stress to smolts could result in decreased survival or migration success.

The orifices we evaluated are shaped like a horseshoe (not round) and, due to their irregular shape, calculating flow is difficult. Flow through the 2-in. (3.8 in.2 area) and 6-in. orifice (27 in. 2 area) was estimated at 0.25 and $-1.7 \mathrm{cfs}$, respectively. Based on the estimated flow and calculated cross-sectional area of the two orifices, the relationship of flow to area is about $0.065 \mathrm{cfs} / \mathrm{in}^{2}$ of opening when the head is about $1.75 \mathrm{ft}$. In order to achieve a flow of 0.8 cfs (IDFG's water right for fish bypass flow), an orifice with about $12.3 \mathrm{in.} 2$ of area would be required ( $\left.0.8 \mathrm{cfs} / 0.065 \mathrm{cfs} / \mathrm{in}^{2}{ }^{2}=12.3 \mathrm{in} .2\right)$. Therefore, a round 4 -in. orifice (12.57 in.2 area) should provide a bypass flow equivalent to the IDFG water right.

Velocity measurements in front of the drum screen and in the fish bypass indicate that bypass flow has only a limited effect on the "flow net" in front of the screens. Depending on which bypass configuration was used, bypass flow accounted for $10 \%$ to $60 \%$ of the total flow entering the screens forebay. As the bypass flow increased, measurable attraction velocities (guiding fish towards the fish bypass) became stronger. However, even when the 6-in. orifice was used and bypass flow was more than half of the total flow, many fry and subyearlings refused to exit through the fish bypass and chose to residualize in the screens forebay. 
The bypass slot in our test system differs from the bypass slot typically used in Idaho. Setting the bypass further away from the drum screen provides a larger transitional area for fish to "acclimate" before passing out the fish bypass. However, setting the orifice gate back may reduce the attraction "flow net" in front of the screens. The screen in our test system was only $4 \mathrm{ft}$ wide. With larger screening facilities, flow net would play an even smaller role in attracting fish to the fish bypass.

Observations with underwater video revealed that many fish would locate the bypass shortly after being introduced into the test system but would not vacate immediately. Passage was affected by bypass configuration, fish size and development stage, fish behavior, weather conditions, and lighting. Subyearling chinook salmon preferred not to move over a weir on bright, sunny days. On rainy and overcast days, more movement occurred during the day. Fish would often hold immediately in front of the orifice or weir for extended periods before falling back tail-first through the bypass. In tests where a significant number of fish remained in the screens forebay throughout the day, peak movement occurred at sundown on the first day. Some fish that stayed in the screen forebay beyond the first nightfall would move out on the second sundown, but most residuals would remain in the forebay until the end of the test.

All movement through the fish bypass appeared to be volitional except when the 6-in. orifice was used during fry tests. With velocities in excess of $1 \mathrm{fps}$, chinook salmon fry entering the bypass slot quickly became fatigued and were unable to avoid being drawn into the orifice. Chinook salmon subyearlings and smolts could escape involuntary passage by maintaining a position at least one body length in front of the 6-in. orifice opening and darting away when they felt threatened. 


\section{Recommendations}

Based on the results of tests with spring chinook salmon fry, subyearlings, and smolts, we strongly recommend that a 2-in. orifice should not be used during the smolt migration period (April through mid-May). A 6-in. orifice or other bypass configuration passing at least $1 \mathrm{cfs}$ of water should be used during these periods whenever possible.

During the summer (mid-May through mid-August) after smolt migration has ceased, smaller orifices with lower flows can be used without significantly impacting movement of spring chinook salmon fry and subyearlings. Following the original recommendations of design engineers from the NMFS, the orifice used in the fish bypass should be as large as is feasible within operational limits as affected by river water levels, head gate and withdrawal capabilities, and location of the screening facility.

At the end of the irrigation season (mid-September through October), and especially prior to canal shutdown, the fish bypass should be equipped with as large an orifice as is possible to allow subyearling chinook salmon to reach downstream overwintering areas and to reduce the risk of residual fish being stranded in the canal upstream of the screening facility. Since subyearling chinook salmon are nearly the same size as smolts, the use of small orifices might cause minor injuries that could affect overwinter survival. Given the depleted condition of salmon runs in the Salmon River Basin, it becomes increasingly important to provide the best conditions for migration and movement that is reasonably possible.

The orifice gate provided by the IDFG should be constructed of a material that is thick enough that the orifices can be beveled to eliminate sharp edges to reduce the possibility of injury to fish. Instead of 1/8-in. steel plate, plastic sheet (1/2 to 3/4 in. thick) could be used. In addition, other intermediate orifice sizes should be available to give operators more control over bypass flow as water needs change throughout the irrigation season. Orifice gates that allow operators to totally shut off bypass flow should not be used unless the gates can be locked in an open position.

Effective communication is imperative among water users, screen operation and maintenance staff, screen fabricators, and design engineers. Irrigators need to be educated and informed about the importance of maintaining bypass flow. Operation and maintenance staff must ensure that the proper orifice gates are in use and report bypass problems to their supervisors. Design engineers must ensure that screening facilities are properly located, built, and operated to meet the water needs of both the irrigators and fish.

These tests demonstrate that fish respond to a wide variety of stimuli that are difficult to control or simulate during an experiment. The modular fish screen installed at a laboratory provides more precise control of conditions and variables than would ever be possible to achieve at a fish screening facility in the field. The most effective and economical method to determine if observed differences (i.e., fish behavior, movement, injury rate) are due to test variables or to other stimuli is through repetitive testing in the laboratory. 


\section{References}

Basham, L.R., M.R. Delarm, J.B. Anthem, and S.W. Pettit. 1982. Fish Transportation_Oversight Team Annual Report. FY 198 1 L Transport Operations on the Snake and Columbia Rivers. Technical Services Division, Northwest Regional Office, National Oceanic and Atmospheric Administration, National Marine Fisheries Service, Portland, Oregon.

Bates, K. 1988. Screen_Criteria for Juvenile Salmon. Washington Department of Fisheries Habitat Division, Olympia, Washington.

Bjom, T.C. 1978. Survival. Production. and Yield of Trout and Chinook Salmon in the Lemhi River.Idaho. University of Idaho, Forest, Wildlife and Range Experimental Station Bulletin 27, Moscow, Idaho.

Clay, C.H. 196 1. Design of Fishwavs and Other Fish Facilities. The Department of Fisheries of Canada, Ottawa, Canada.

Cohen, J. 1977. Statistical Power Analysis for the Behavioral Sciences. Prentice-Hall, New York.

Easterbrooks, J.A. 1984. Juvenile Fish Screen Design Criteria: A Review of the Objectives and Scientific Data Base. Washington State Department of Fisheries, Habitat Management Division, Yakima, Washington.

Grant, Douglas M. 1992. Isco Open Channel Flow Measurement Handbook. Third edition. Isco Environmental Division, Lincoln, Nebraska. pp 4 1-43.

Green, R.H. 1989. Power Analvsis and Practical Strategies for Environmental_Monitoring. Environmental Research 50: 195-205.

Mainland, D., L. Herrera, and M. I. Sutcliffe. 1956. Tables for Use with Binomial Samples Mainland, Herrera, and Sutcliffe, New York.

Neitzel, D.A., C.S. Abemethy, E.W. Lusty, and L.A. Prohammer. 1985. A Fisheries Evaluation of the Sunnvside Canal Fish_Screening Facility_Soring 1985. Prepared by the Pacific Northwest Laboratory for the Division of Fish and Wildlife, Bonneville Power Administration, Portland, Oregon.

Neitzel, D.A., C.S. Abemethy, and E.W. Lusty. 1986. AFisheries Evaluation of the Richland and Toppenish/Satus Canal Fish Screw Facilities. Spring 1986. Prepared by the Pacific Northwest Laboratory for the Division of Fish and Wildlife, Bonneville Power Administration, Portland, Oregon. 
Neitzel, D.A., C.S. Abemethy, E.W. Lusty, and S.J. Wampler. 1988. A Fisheries Evaluation of the Richland and Wapato Canal Fish Screening_Facilities. Spring 1987. Prepared by the Pacific Northwest Laboratory for the Division of Fish and Wildlife, Bonneville Power Administration, Portland, Oregon.

Neitzel, D.A., C.S. Abemethy, and E.W. Lusty. 1990a. A Fisheries Evaluation of the Wapato, Sunnyside, and Toppenish Creek Canal Fïsh Screening_Facilities_Spring_1988. Prepared by the Pacific Northwest Laboratory for the Division of Fish and Wildlife, Bonneville Power Administration, Portland, Oregon.

Neitzel, D.A., C.S. Abemethy, and E.W. Lusty. 1990b. A Fisheries Evaluation of Westside Ditch and Wapato Canal Fish Screening Facilities Spring 1989. Prepared by the Pacific Northwest Laboratory for the Division of Fish and Wildlife, Bonneville Power Administration, Portland, Oregon.

Neitzel, D.A., C.S. Abemethy, and E.W. Lusty. 1990c. A Fisheries Evaluation of the Westside Ditch and Town Canal Fish Screening Facilities Spring 1990. Prepared by the Pacific Northwest Laboratory for the Division of Fish and Wildlife, Bonneville Power Administration, Portland, Oregon.

Neter, J., W. Wasserman, and M.H. Kutner. 1985. Applied Linear Statistical Models: Regression, Analysis of Variance, and Experimental Designs. Richard D. Irwin, Inc., Homewood, Illinois.

Snedecor, G.W., and W.G. Cochran 1967. Statistical Methods. Iowa State University Press, Ames, Iowa. 